\title{
Amaç ve Politikalar Açısından Yerel Yönetimler: Onuncu ve On Birinci Kalkınma Planları Karşılaştırmalı Analizi
}

\author{
Local Governments in Terms of Objectives and Policies: Comparative Analysis of the Tenth and \\ Eleventh Development Plans
}

\author{
Serif ÖNER \\ Doç. Dr., Ballkesir Üniversitesi, IIIBF, \\ Siyaset Bilimi ve Kamu Yönetimi Bölümü, \\ https://orcid.org/0000-0002-9446-7394
}

Makale Başvuru Tarihi: 19.10.2019

Makale Kabul Tarihi: 30.12.2019

Makale Türü: Araştırma Makalesi

\section{Anahtar \\ Kelimeler: \\ Kalkınma \\ Planlarl,}

Yerel Yönetimler,

Yerel Demokrasi,

Değişim,

Katılım,

\section{Keywords: \\ Development Plans,}

Local Government,

Local Democracy,

Change,

Participation,

\section{ÖZET}

Toplumsal taleplere bağlı olarak kamu hizmetlerinin etkin-verimli sunulması kurumların öncelikli amaçlarıdır. Mevcut kurumlar öngörülen amaçlara erişmek noktasında her zaman başarılı olamamıştır. Ekonomik, sosyal, siyasal, enformatik vb. alanda yaşanan değişimler kurumların işleyişinde ciddi sorunlar ortaya çıkarmışıtır. Mevcut yöneten-yönetilen ilişkisinin sıkışıp kaldı̆̆g demokrasi uygulamaları sorunların çözümünde yetersiz kalmıştır. Sorunları aşmak için kamu kesimi, özel sektör ve yerel unsurların birlikte hareket etmesi bir seçenek olarak belirlenmiştir. Toplumsal, küresel ve bölgesel ölçekli sorunların çözümünde demokrasi ve katılım aracı öne çıkarılmıştır. Evrensel yönetim anlayışı açısından katılım ve demokrasi uygulamaları için temel uygulama alanı yerel yönetimlerdir. Ülkemizde kurumsal açıdan yerel yönetimler Tanzimat reformları ile ortaya çıkmıştır. Cumhuriyetin ilanıyla gerçekleşen reformlardan yerel yönetimlerde (özellikle belediyelerde) etkilenmiş ve yasal-kurumsal değişimler gerçekleştirilmiştir. Yerel yönetimler planlı kalkınma dönemi ile kapsamlı şekilde ele alınmaya başlanmıştır. Yerel yönetimlerin idari, mali sorunları, kentleşme ve köy kalkınması öne çıkmıștır. Avrupa Birliği ile kurulan ilișkilere bağlı olarak demokrasi ve katılım kavramlar yerel yönetimlere daha etkin şekilde yansitılmıştır. Süreç içinde modern yönetim araçları yerele aktarllmaya çalışılmıştır: yönetişim, özerklik, açıklık, stratejik planlama, performans yönetimi, vb. Ayrlca, merkezi yönetim tarafindan yerel yönetimlere ilişkin mali ve idari sorunlar öne çıkarılmış ancak tatmin edici çözümler üretilememiştir. Türkiye'de, 1963'den günümüze on tane kalkınma planı hazırlanmış ve 23 Temmuz 2019'da 11. plan yürürlüğe girmiştir. İçeriği itibariyle kalkınma planları tüm sektörlere ve sorun alanlarına yönelik hedefler belirlemektedir. Ülkemizde hazırlanan kalkınma planları yerel yönetimlerle ilgili politika ve hedeflere yer vermiștir. Çalışmamızda dönemsel açıdan son iki plan ele alınmaktadır: on ve on birinci plan. İlgili planlar yerel yönetimlere ilişkin öngördükleri politika ve amaçlar açısından ele alınmaktadır. 11. Kalkınma planının içeriğinde geçmiş dönem planlarına ait atıflar bulunmakta ve büyükşshirlere yönelik reform öngörülmektedir. Ayrlca; insan odaklı şehir, yeşil şehir, akıllı şehir, katılımcılık, şeffaflık, hesap verilebilirlik, vb. konulara yer verilmektedir. Tüm bu yaklaşımlar 11. plan döneminde yerel yönetimlere ilişkin değişimin devam edeceğini göstermektedir.

\section{ABSTRACT}

Active and efficient provision of public services depending upon the social demands are the primary objectives of the institutions. Existing institutions have not always been successful in the foreseen objectives. Changes experienced in the economic, social, political, informatics, etc. fields have created serious problems for the functioning of institutions. Democracy practices, which have gone into a stalemate in the current ruler-ruled relationships, have remained incapable of solving the problems. The joint action of the public sector, the private sector and the local elements have been identified as an option to overcome the problems. In the solution of social, global and regional problems, the instrument of democracy and participation has been highlighted. In terms of universal governance, the fundamental application field for the participation and democracy practices is the local governments. In our country, local governments with respect to institutional approach emerged with Tanzimat reforms. Local governments were also affected by the reforms made with the proclamation of the Republic (especially in municipalities) and legal-institutional changes were realized. Local governments had started to be comprehensively taken into hand with the planned development period. Administrative, financial problems of local governments, urbanization and village 
ÖNER, Şerif - Amaç ve Politikalar Açısından Yerel Yönetimler: Onuncu ve On Birinci Kalkınma Planları Karşılaştırmalı Analizi

development came to the forefront. With the relations established with the European Union, the concepts of democracy and participation were reflected more effectively to the local governments. In the process, modern management tools were attempted to be applied on the local level: governance, autonomy, accountability, strategic planning, performance management, etc. Moreover, financial and administrative problems related to local governments were brought forward by the central government, but no satisfactory solutions were produced. In Turkey, ten development plans have been prepared since 1963 and the 11th plan came into force on July 23, 2019. In terms of content, development plans set targets for all sectors and problem areas. Development plans prepared in our country included policies and targets related to local governments. In our study, the last two plans are discussed periodically: the tenth and eleventh plans. The relevant plans are discussed in terms of the policies and objectives they envisage for local governments. $11^{\text {th }}$ the development plan content includes references to past plans and reforms that were envisaged for metropolitan cities. Topics such as people-oriented city, green city, smart city, participation, transparency, accountability, etc. were also included. All these approaches indicate that the changes regarding the local governments will continue in the 11th Plan period.

\section{GÍRIŞ}

Türkiye'nin tüm kurumsal ve yapısal gelecek yönelimli perspektifleri açısından hedef ve beklentilerine ilişkin yol haritası olarak nitelenecek olan kalkınma planları dönemsel olarak keynezyen politika ve uygulamalarının temel bir aracı olarak yönetsel gündemimize girmiştir. Öngörülen temel beklentiler/hedefler ile çıktılar/ulaşılan sonuçlar arasında isabetsizliklerin dış ve iç konjontürel nedenler ile açıklanabilmesinin yanında kalkınma planlarının dönemsel olarak yönetsel, kurumsal, toplumsal gelecek beklentilerinin şekillenmesi ve politika araçlarının belirlenmesi noktasında önemli katkıları olmuştur. Kalkınma planları aracılığıyla ülkemizin planlama konusunda tüm kurum ve kuruluşların edindiği birikim, donanım, yetiştirilen insan kaynağı ve tüm bu faktörlerin sürece katkıları devasa bir planlama hafızasını ortaya çıkarmıştır. Yirmi birinci yüzyılın siyasal, sosyal, ekonomik pek çok parametreye bağlı küresel gerçekleri, zorlayıcı şartları kaçınılmaz biçimde iç dinamiklerimizi gelecek beklentilerimizi vizyonel bakışımızı etkilemektedir. Toplumsal kesimlerin temel yaşam beklentilerinin ve gelecek planlarının daha bilinçli şekilde ele alınması yönündeki organize ve ısrarlı talepleri kalkınma planı (ve uygulanan biçimi ile stratejik plan) olgusunun önemini daha da arttırmış görünmektedir.

Siyasal, sosyo-ekonomik rekabetçi küresel gerçeklerin karmaşık bir hal alması kent ve bölgesel ölçekte artan nüfus yoğunluğu, çarpık kentleşme, kontrolsüz göç, işsizlik, sosyal refah ve güven ortamının zedelenmesi, çevresel kirlilik vb. nicelik ve nitelik bakımından çeşitlenen sorunlar yaşamsal beklentilerin ve gelecek planlarının yeni şartlara göre revize edilmesini ve bunun çağın gerektirdiği demokratik, sosyal, kültürel gelişmişlik ölçeklerine göre geniş bir yelpazede ele alınmasını artan düzeyde gerekli kılmaktadır. Küresel ölçekte yaşanan iç ve bölgesel çekişmelere endeksli görünen ekonomik ve siyasal belirsizliklerin sosyoekonomik ve siyasal etki alanı açısından yeni paylaşım kümeleri ve ilkeleri ortaya konmadan çözül(e)meyecek görünmesi, toplumların iç ve dış dinamiklerini göze alan kalkınma politika ve hedeflerini etkin ve akılcı planlamalarını dünden daha çok zorunlu kılmaktadır. Günümüz gerçekliği içinde kalkınma olgusu (belirleyici etki faktörü özelliğini korumakla birlikte) tek başına ekonomi parametresi içine sıkıştırılamayacak kadar önemli ve kompleks bir nitelik kazanmıştır. Zamanın ve koşulların gereği yaşamsal taleplere erişilebilirlik için bireysel ekonomik güç ne kadar belirleyici ise üretim-tüketim dengesi başta olmak üzere küresel rekabet şartları ile mücadele edebilen devletler için yerel ve ulusal ekonomik gelişmişlik küresel ve bölgesel ölçekte etkin ve sürdürülebilir güç olabilmenin temel faktörlerinden olmaya devam etmektedir.

Küresel/bölgesel ölçekte yine ve yeniden değişim/dönüşüm beklentisi çerçevesinde ülkemizin sosyo-ekonomik, siyasal, sosyal vb. tüm toplumsal kesimlerini bekleyen önemli görevler olduğu açıktır. Söz konusu değişim ve dönüşüm beklentilerine ilişkin rol modellerin yeniden tanımlanması gereken alanlardan biri de kentsel yaşam alanlarıdır. Öyleki, küresel ölçekte kent ölçeğinin son dönemlerde kavramsallaştırılmaya başlanan "kent-bölge ölçeğì" içindeki ikincil konumu/rolü bu alanların ivedilikle küresel yeni sosyo-ekonomik ve yönetsel şartlara hazır hale getirilmesini gerektirmektedir. Türkiye'de yaşadığımız kentleşme olgusunun olumsuz ve zamanla kontrolden çıkan etkileri kalkınma planı anlayışının en önemli başlıklarından biri olmuştur. Bugüne kadar uygulanan on kalkınma planının başlıklarından biri kentleşme ve kentleşme ile ortaya çıkan yönetsel, yapısal, kurumsal, çevresel sorunlara ilişkin politika arayışları olmuştur.

Çalışmamızda yirmibirinci yüzyılın ilk çeyreğinden elde edilen tecrübelere bağlı gelecek planlamasına ilişkin önemli küresel ve bölgesel atıfların yapıldığı on birinci kalkınma planı (2019-2023) 2017 referandumu ile kabul edilen yönetim sisteminin (Cumhurbaşkanlığı Hükümet Sistemi) ilk planı olması dolayısıyla da kentsel yerleşim alanlarına ilişkin kurumsal/yönetsel yaklaşım ve politikaların belirlenmesi açısından ilgi çekici olmuş, ayrıca on birinci plan ile bir önceki onuncu kalkınma planında yer alan kentsel yaşam alanına ilişkin sorun alanları, çözüm önerileri ve politika araçlarının karşılaştırma ve analizine yer verilmiştir. 


\section{KALKINMA PLANLARININ DÖNEMSEL ANALİİ (2014-2023)}

Çalışmamız Adalet ve Kalkınma Partisi iktidarları döneminde hazırlanan kalkınma planlarının dönemsel analizine yönelik olarak iki ayrı hükümet sisteminin çıktısı olan iki ayrı plan ele alınacaktır. Bu çerçevede Parlamenter Hükümet Sisteminin son kalkınma planı ile (onuncu) ve Cumhurbaşkanlığı Hükümet Sisteminin (CHS) birinci kalkınma planı olan (on birinci) kalkınma planları yerel yönetimler yaklaşımları açısından incelenecektir.

\subsection{Onuncu Kalkınma Planı ve Yerel Yönetimler Vizyonu (2014-2018)}

Recep Tayyip Erdoğan'ın Başbakanlığında kurulan 61. Hükümet tarafından hazırlanan Onuncu Kalkınma Planı TBMM'de 02.07.2013'de onaylandıktan sonra (06.07.2013) Resmi Gazete'de yayınlanmıştır.

Strateji ve Genel Özellikler: Onuncu kalkınma planı, 2023 hedefleri doğrultusunda, vatandaşları yüksek refah seviyesine ulaştırma hedefine odaklanmıştır. Türkiye'nin sosyo-ekonomik kalkınma süreci bütüncül şekilde ele alınırken, insan odaklı kalkınma anlayışı ve katılımcı yaklaşım benimsenmiştir. Planda kalkınmanın öngörülen temel amac1; "insanların refahını artırmak, hayat standartlarını yükseltmek, temel hak ve özgürlükleri güçlendirerek adil, güvenli, huzurlu yaşam ortamı tesis etmek ve kalıcı kılmak" (10. KP, 2014:2) olarak belirlenmiştir. Planın hazırlanmasında Devlet Planlama Teşkilatından aktarılan deneyimlerle Kalkınma Bakanlı̆̆1 öncülüğünde komisyon raporlarından, kamu,özel sektör, sivil toplum-düşünce kuruluşları ile akademik çevrelerin görüş ve önerilerinden geniş biçimde yararlanılmıştır. Planının hazırlık sürecine katkı veren toplam 49 ihtisas komisyonundan biri "yerel yönetimler komisyonu” olmuştur.

Temel amaçlar ve ilkeler: Uzun vadeli planın kalkınma amacı; "yeniden şekillenmekte olan dünyada milletimizin temel değerlerini ve beklentilerini esas alarak gerçekleştirilecek yapısal dönüşümlerle ülkemizin uluslararası konumunu yükseltmek ve halkın refahını artırmak" (10. KP, 2014:27) olarak belirlenmiştir. İnsan odaklı kalkınma anlayışı ile; hem bireysel hem toplumsal nitelik ve yapabilirliklerin yükseltilmesi sonucunda bireylerin kendilerini geliştirmelerinin sağlanması ile sosyo-ekonomik yaşamda daha aktif katılım sergilemeleri ve yoksulluğun azaltılarak toplumsal refahın geliştirilmesinin temel alınacağı belirtilmişstir (10. KP, 2014:27).

Çalışmamızla doğrudan ilgili temel vurgu olması dolayısıyla planda; "şehirlerin ve kırsal alanların kendine özgü koşul ve niteliklerine göre, daha iyi iş firsatlarını ve yaşam ortamlarını sunabilir hale gelmesi”" (10. KP, 2014:28) temel amaçlar arasında sayılmıştır. Bu doğrultuda belirlenen hedefler ise şunlardır; Bölgeler arası gelişmişlik farklarının azaltılması; Bölgelerin ve kentlerin rekabet güçlerinin geliştirilmesi; Yerleşimlerde temel yaşam kalitesi standartlarının oluşturulması; Düşük gelirli bölge ve şehirler başta olmak üzere ulaştırma, lojistik ve iletişim altyapısının iyileştirilerek piyasalara ve kamu hizmetlerine erişimin kolaylaştırılması ve gelişmiş bölge ve şehirlerin küresel ekonomiyle bütünleşmenin güçlendirilmesidir. $\mathrm{Bu}$ temel amaçlara ulaşırken kalkınma sürecinin siyasi ve toplumsal düzeyde sahiplenilerek bütüncül bir yaklaşımla sürdürülmesinde, insan odaklılık, katılımcılık, kapsayıcılık, hesap verebilirlik ve şeffaflık ilkeleri esas alınacaktır (10. KP, 2014:28).

\subsection{On Birinci Kalkınma Planı ve Yerel Yönetimler Vizyonu (2019-2023)}

Cumhurbaşkanı Recep Tayyip Erdoğan tarafindan teşekkül ettirilen CHS'nin ilk kabinesi 9 Temmuz 2018'de 16 Bakanlık ve 1 Cumhurbaşkanı yardımcısı olmak üzere 1 nolu Cumhurbaşkanlığı Kararı ile atanmıştır. Türkiye Cumhuriyeti'nin On Birinci, CHS'nin ise Birinci Kalkınma Planı 18 Temmuz 2019'da TBMM'de Genel Kurulunda onaylanmış ve 23 Temmuz 2019' da yayınlanmıştır.

Strateji ve Genel Özellikler: Plan, istikrarlı ve güçlü ekonomi, rekabetçi üretim ve verimlilik, nitelikli insan ve güçlü toplum, yaşanabilir şehirler ve sürdürülebilir çevre ile hukuk devleti, demokratikleşme ve iyi yönetişim gelişme eksenleri olmak üzere beş temel eksenden oluşmaktadır. Planda öngörülen politika ve tedbirlerin etkin bir biçimde hayata geçirilmesini teminen Cumhurbaşkanlığı Programı, orta vadeli programlar (OVP), Cumhurbaşkanlığı yıllık programları, bölgesel gelişme ve sektör stratejileri, kurumsal stratejik planlar Kalkınma Planı esas alınarak hazırlanacaktır. CHS'nin yürütmenin hızlı ve etkili yapısıyla Kalkınma Planının idarelerce etkin şekilde uygulanması amaçlanmaktadır. (11. KP, 2019:1-3).

On Birinci Kalkınma Planının hazırlanmasına ilişkin koordinasyon görevi 2017'de yayınlanan 2017/16 sayılı Başbakanlık Genelgesi ile Kalkınma Bakanlığına verilmiş ve çalışmalara başlanılmıştır. İlerleyen süreçte yayınlanan CB Kararnamesi ile Cumhurbaşkanı tarafindan belirlenen temel hedef, ilke ve amaçlar çerçevesinde 
kalkınma planı hazırlama görevi (Politika Kurullarının da görüşlerini almak suretiyle) Cumhurbaşkanlığı Strateji ve Bütçe Başkanlığı ile Hazine ve Maliye Bakanlığına müşterek görev olarak verilmiştir (13 nolu C.K.). Plan, bakanlıklar, kamu kurum ve kuruluşları ile tüm toplumsal kesimlerden çok sayıda temsilcinin katkılarıyla geniş bir katılımcı uygulamayla hazırlanmıştır. Kamu, özel sektör ve sivil toplum kuruluşu temsilcisi ve akademisyenin katkı verdiği 75 ihtisas komisyonu ve 32 çalışma grubu oluşturulmuş, ülke çapında 81 ilde 267 toplantı düzenlenmiştir. Katılımın yaygın kılınmasına yönelik olarak yerel düzeyde yaklaşık 12 bin kişinin görüş ve önerisi alınmış ayrıca internet üzerinden "vatandaş anketi" uygulamasıyla 19 binden fazla kişiye ulaşılmıştır (Şekil 1).

Şekil 1. Planın Künyesi: Süreç ve Yönetsel İlişkiler

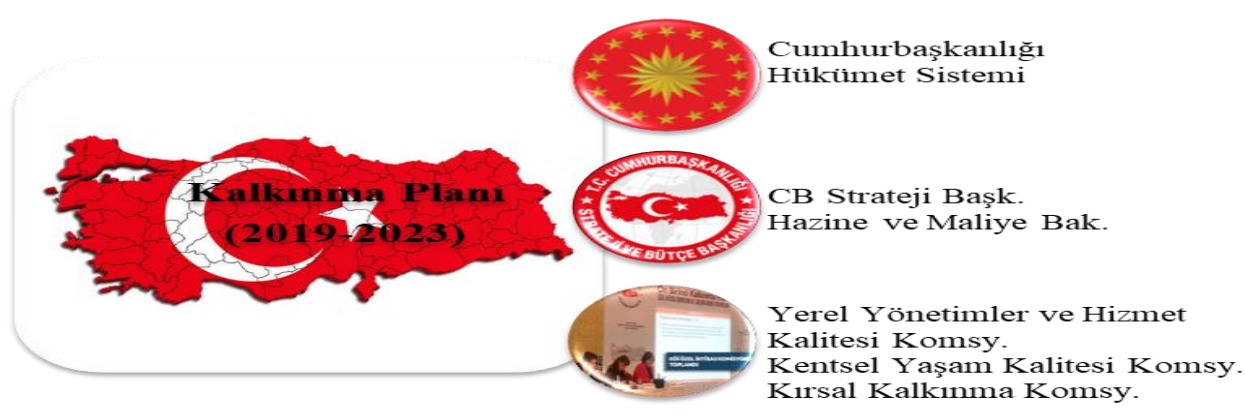

Kaynak: Yazar tarafindan hazırlanmıştır.

Temel amaç vizyon ve ilkeler: On birinci kalkınma planı, "daha fazla değer üreten, daha adil paylaşan, daha güçlü ve müreffeh Türkiye” (11. KP, 2019:26) olarak belirlenen uzun vadeli vizyon öngörürmenin yanında kalkınmanın temel amaci (11.KP, 2019:26);

"milletimizin temel değerlerini ve beklentilerini esas alarak ülkemizin uluslararası konumunu yükseltmek ve halkımızın refahını artırmak; Türkiye'nin yüksek gelir grubu ülkeler ile en yüksek insani gelişmislik seviyesindeki ülkeler arasına girmesi; vatandaşların mutlu, sağllkll, güvenli yaşam sürebilecekleri, temel hak ve özgürlüklerin adil ve hizlı çalışan bir hukuk sistemiyle korunmasının yanı sıra öngörülebilirliği yüksek kamu politikalarıyla, firsat eşitliğine dayalı, kolay erişilebilir ve vatandaş odakl kamu hizmetleri sunulması",

olarak belirlenmiştir. Söz konusu vizyon ve amaçlar çerçevesinde plan ilkeleri (11. KP, 2019:26);

"insan odakl kalkınma anlayışlyla toplumsal refahın yaygınlaştırılması doğrultusunda şehirlerin ve kırsal alanların daha iyi iş firsatlart ve yaşam ortamlart sunabilir hale getirilmesi; bireysel ve toplumsal nitelik ve yetkinlik düzeylerinin yükseltilmesi, sosyal güvenlikle ilgili düzenlemeler ile doğal kaynakların kullanılmasında nesiller arası hakkaniyet ve sürdürülebilirliğin sağlanması ve insan odaklılık, katılımcılık, kapsayıcılık, hesap verebilirlik, şeffaflık ve verimlilik",

olarak sıralanmıştır.

\section{KENTSEL ALAN TEMEL YAKLAŞIMLARI VE PLAN KARȘILAŞTIRMASI}

Her iki kalkınma planında kentsel yaşam alanı temel gelişme ve sorun alanları özelinde ele alınmıştır. Aşağıda planların yaşanabilir mekanlar ve sürdürülebilir çevre başlıkları altında ele aldıkları hedef ve politika öngörüleri karşılaştırılacaktır (Şekil 2.).

Şekil 2. Yaşam Alanları Özelinde Genel Hedef ve Politikalar
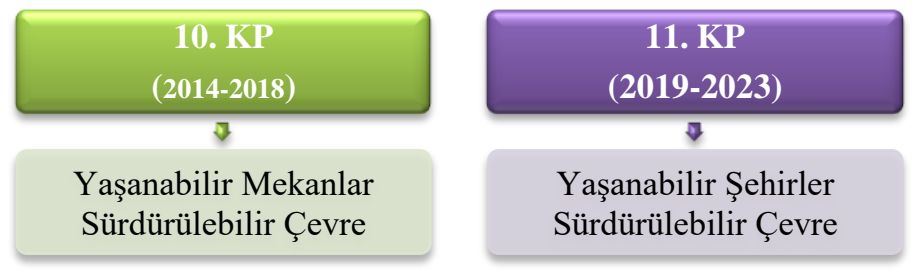

Kaynak: Yazar tarafindan hazırlanmıştır. 


\subsection{Yaşanabilir Mekânlar, Sürdürülebilir Çevre (10. KP)}

Planda yaşam ortamlarının kalitesi temel kalkınma ve refah göstergelerinden biri kabul edilmekte, kırsal kesimin güçlendirilmesi ve şehirleşmenin dengeli oluşmasının sağlanması için insanı ve yaşam kalitesini daha çok merkeze alan yaklaşıma olan ihtiyaç vurgulanmaktadır. Şehirlerimizin temel sorunları olarak; aşırı ve niteliksiz büyüme; barınma; trafik; güvenlik; altyapı; sosyal uyum ve çevre sorunları gösterilmiştir. Şehirlerimizin hem yaşanan mevcut sorunların çözümü hem de küresel işleyişin geldiği nokta itibariyle yatırım imkanları için uygun alanlar olarak öne çıkabilmelerine yönelik çözüm önerisi olarak;

- Şehirlerimizin önemli bir kısmının, uygun müdahalelerle yaşanabilir mekânlara dönüştürülmesi,

- Kentsel imaj yönetimi ve markalaşma çabalarıyla çekim merkezi olmasının sağlanması gereği öne çıkarılmıştır.

Planın temel yaklaşımları şu başlıklar altında toplanabilir. Birincisi: İnsanların yaşam ortamlarının kalitesi kalkınma ve refah göstergesi olarak öngörülmüştür. İkincisi: Kırsal kesimin güçlendirilmesi ve şehirleşmenin dengeli oluşması çabalarında temel unsurlar olarak, insanı ve yaşam kalitesini daha çok merkeze alan yaklaşım ihtiyacı vurgulanmıştır. Üçüncüsü: Küresel rekabet şartları ile ülke olarak payımıza düşeni alabilmek, jeopolitik avantajlarımızı görünür kılabilmek için bölgesel, kent ve kır ölçeklerinde ortaklaşa çözümler üretilmesi gereği öne çıkarılmıştır. Dördüncüsü: Biraz iyimser bir ifadeyle olsa gerek, şehirlerimizin önemli bir kısmının uygun müdahalelerle yaşanabilir mekanlar haline dönüştürülebileceğinden söz edilmiştir. Beşincisi: plan ile Türkiye'nin kentleşme vizyonuna, kentsel imaj ve markalaşma kavramları dahil edilmiştir (10. KP, 2014:117118). Yaşanabilir mekanlar, sürdürülebilir çevre başlı̆̆ında ayrıca 9 konuya yer verilmiştir;

- Mekânsal gelişme ve planlama;

- Kentsel dönüşüm ve konut;

- Kentsel altyap1;

- Mahalli idareler;

- Kirsal kalkınma;

- Bölgesel gelişme ve bölgesel rekabet edebilirlik;

- Çevrenin korunması;

- Toprak ve su kaynakları yönetimi;

- Afet yönetimi.

\subsection{Yaşanabilir Şehirler Sürdürülebilir Çevre (11. KP)}

On birinci planın 5 temel eksende ele alınan hedef ve politika başlıklarından biri olan yaşanabilir şehirler ve sürdürülebilir çevre alt başlığında yapılan genel değerlendirmeler içinde hızlı nüfus artı̧̧ı ve şehirleşmenin çevresel kaynaklar üzerindeki baskı unsurlarından biri olduğu vurgulanmıştır. Bu çerçevede yaşanabilir kentlerin inşası için sürdürülebilir çevre ve doğal kaynak yönetiminin etkili şekilde yürütülmesinin önemine işaret edilmiştir.

Planın temel yaklaşımları şu başlıklar altında toplanabilir. Birincisi: ülkemizdeki yaşam alanlarına ilişkin politika perspektifleri oluşturulurken kentle bütünleşen temel hizmet türlerinin "adil ve erişilebilirliğinin sağlanması" (11. KP, 2019:170-187) yerel ihtiyaçların yerindelik ilkesi çerçevesinde kalitesi yüksek yaşam alanı oluşturma hedefi ile sunumu öngörülmüştür. İkincisi: sadece kent yaşamı değil kırsal yaşamın kalifikasyonuna yönelik ekonomik ve sosyal desteklere yer verilmiştir. Üçüncüsü: kentlerin sürdürülebilir gelişimi kavramı öngörülmüş bu çerçevede politika süreçleri ve uygulama aşamalarında tüm paydaşların katılımı ve kapsamlı işbirliğinin gerekliliğine işaret edilmiştir. Dördüncüsü: insan odaklı yatay mimari öngörülmüştür. Beşincisi: kentsel dönüşüm projelerinde kamunun rolünün arttırılması ve sürece ilişkin katılım kanallarının geliştirilmesine yer verilmiştir. Yaşanabilir Şehirler Sürdürülebilir Çevre konulu hedef ve politikalar 8 alt başl1kta toplanmıştır (11. KP, 2019:170-187); 
1. Şehirleşme,

2. Konut,

3. Kentsel dönüşüm,

4. Kentsel altyap1,

5. Kirsal kalkınma,

6. Bölgesel gelişme,

7. Çevrenin korunması

8. Afet yönetimi.

\section{AMAÇ VE POLITIKALALAR AÇISINDAN PLAN KARȘILASTTIRMASI}

Onuncu ve On birinci kalkınma planları genel eksenler açısından olduğı kadar kent-kır-bölge odaklı kentsel yaşam alanlarına yönelik sorun ve politika tespitleri açısından da önemli benzerlikler göstermektedir (Şekil 3).

Şekil 3. Kentsel Alan Sorun ve Politika Başlıkları
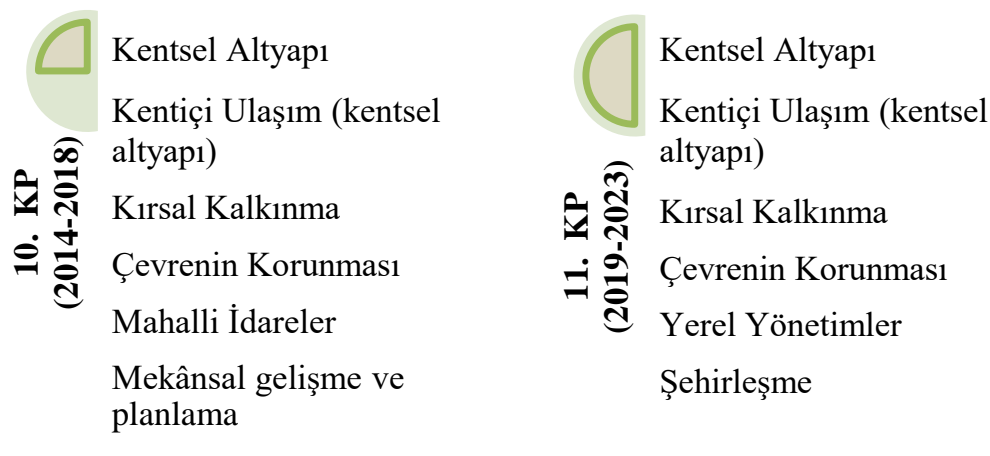

Kaynak: Yazar tarafindan hazırlanmıştır.

\subsection{Kentsel Altyapı: Amaç ve Politikalar}

Kentsel altyapı dönemsel değil süregelen bir sorun alanı olmasına ilişkin perspektif her iki plan içeriğine de yansımıştır. Aşağıda kentsel altyapı başlığı altında ele alınan sorun alanları ve temel politika önerilerine yer verilmektedir.

Kentsel altyapı (10. KP): Yerel yönetimler açısından planın önemli noktalarından biri olan kentsel altyapı başlığında mevcut durum analizine yönelik olarak; Hızlı şehirleşmeye bağlı olarak ortaya çıkan ulaşım, sukanalizasyon altyapısı konusunda artan ihtiyaç taleplerine atıf yapılmış, faydalarının yeterince bilinmemesi vb. nedenlere bağlı olarak geri dönüşüm konusunda yeterli ilerleme sağlanamadığ 1 vurgulanmıştır (10. KP, 2014:128-131). Planda sağlıklı içme-kullanma suyuna erişim ve etkin atık yönetimi hedeflenmiştir. Söz konusu hedeflere erişilmesi için öngörülen politika araçları şunlardır:

1. Gerekli kalite ve standartlarda olmak üzere içme-kullanma suyu ihtiyaçlarının karşılanması ve atık su arıtma altyapısının geliştirilmesi.

2. İçme suyu ve kanalizasyon yatırım ve hizmetlerinde mali sürdürülebilirliğin gözetilmesi.

3. Etkin atık yönetimi ile geri dönüştürülen malzemenin kullanımının özendirilmesi.

4. Kentsel altyapı hizmetlerinin sunumunda teknoloji kullanımı etkinleştirilmesi.

Kentsel altyapı (11. KP): Nüfusun sağlıklı ve güvenilir içme ve kullanma suyuna erişiminin sağlanması ve etin atık su yönetiminin gerçekleştirilmesi temel amaç olarak belirlenmiştir. Kentsel altyapı konusunda plan amaçlarına erişilmesini sağlayacak politika başlıkları ise şunlardır: 
1. Su kaynaklarının korunması, geliştirilmesi ve sürdürülebilir kullanımı için kuraklık yönetim vb. strateji ve eylem planlarının uygulanması.

2. Atıksuların arıtıldıktan sonra (başta tarımsal faaliyetlerde) yeniden kullanılması.

3. İçme suyu ve atıksu hizmetlerinin standartlara uygun sunulması.

4. Ulusal su bilgi sisteminin yaygınlaştırılması ve Sukap programının geliştirilmesi.

5. Büyükşehir belediyesi harici illerde bazında su kanalizasyon idarelerinin kurulması.

6. Etkin katı atık yönetimi sağlanması ve Sıfır Atık Projesi’nin yaygınlaştırılması.

7. Geri kazanım projelerinin uygulanması için yerel yönetimlere finansman desteği sağlanması.

8. Kentlerde imar uygulamalarına yönelik koordinasyon mekanizması kurulması. Söz konusu politikalar çerçevesinde 2023 yılı itibariyle arıtılmış atık suların yeniden kullanımı \%10'a çıkarılması; İçme suyu kayıp kaçak oranının \%25'e düşürülmesi hedeflenmektedir.

Karşılaştırma ve Analiz: Kentsel altyapı politika ve amaçları açısından 10. plan içme suyu ve kanalizasyon altyapısının tamamlanması ve bu konuda mali sürdürülebilirliğe atıf yaparken 11. plan bu konuda su bilgi sistemi, sukap ve kurumsal yapılanma gibi kurumsal, stratejik ve eylem planı ağırlıklı politika perspektifi öngörmektedir. 10. Plan atık yönetimini etkin kılmayı, 11. plan ise daha somut bir uygulama olarak sıfır atık projesinin yaygınlaştırılmasını öngörülmektedir. Bu çerçevede 11. plan kentsel altyapı açısından stratejik bakış ve eylem odaklı politikalara yer vermektedir (Şekil 4).

Şekil 4. Kentsel Altyapı Politikalarının Karşılaştırması
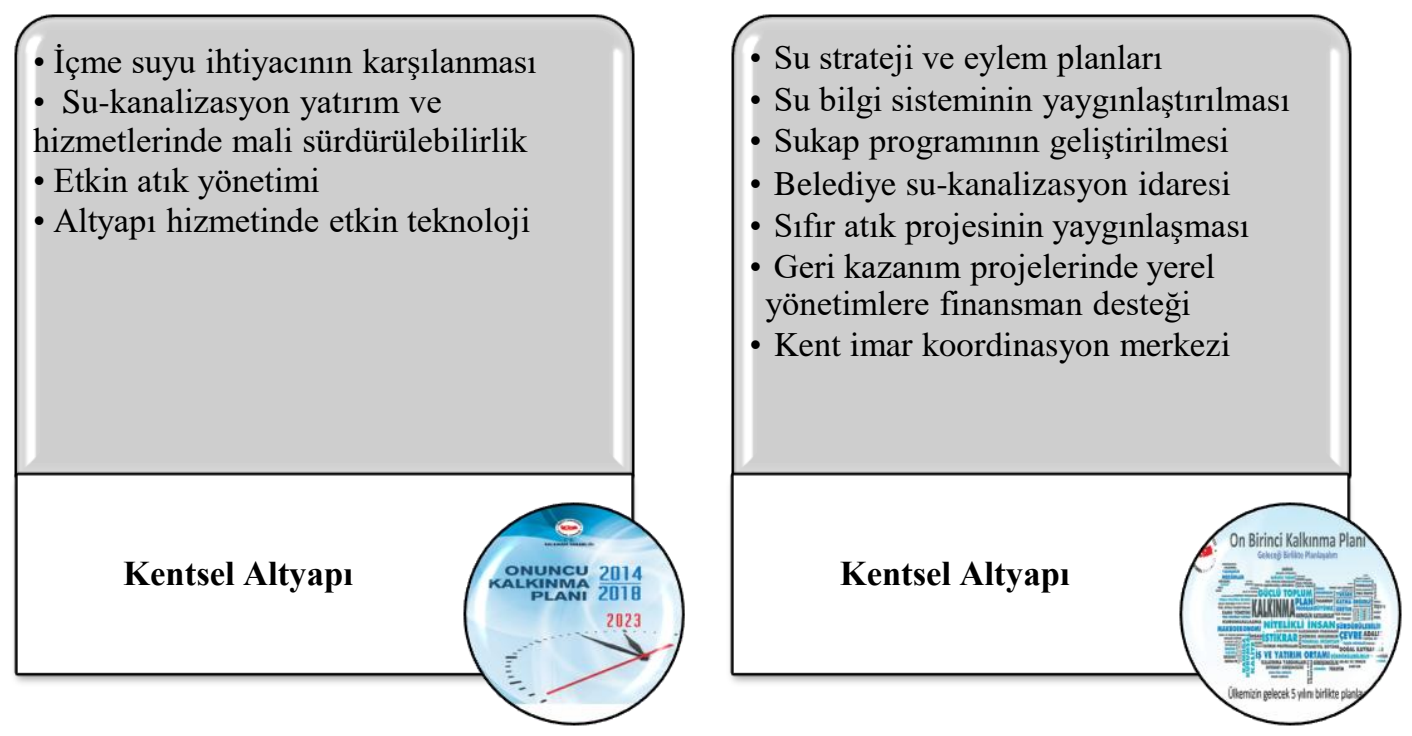

Kaynak: Yazar tarafından hazırlanmıştır.

\subsection{Kentiçi Ulaşım: Amaç ve Politikalar}

Kentiçi ulaşım konusu her iki planda da ayrı bir başık olarak ele alınmamış ve kentsel altyapı başlığı içinde amaç ve politikalar belirlenmiştir.

Kentiçi ulaşım (10. KP): Trafik sıkışıklığını azaltan, erişilebilirliği ve yakıt verimliliği yüksek, konforlu, güvenli, çevre dostu, maliyet etkin ve sürdürülebilir bir ulaşım altyapısının oluşturulması temel amaç olarak belirlenmiştir (10. KP, 2014:128-131). Söz konusu temel amaca ulaşmak noktasında öngörülen politikalar şunlardır:

1. Kentiçi toplu taşımada alternatif araçlara yönelinmesi.

2. Kentiçi ulaşımda kurumlar arası koordinasyon geliştirilmesi.

3. Yaya, bisiklet vb. alternatif ulaşımın özendirilmesi. 
4. Büyükşehir kentiçi raylı sistem projelerinin farklı ulaşım güzergahları ile entegre edilmesi.

5. Kentiçi ulaşımda akıllı ulaşım sistemlerinin etkin kullanımı.

Kentiçi ulaşım (11. KP): Ülkemizin metropol yerleşimlerinin birincil sorunlarından olan kentiçi ulaşıma yönelik planda; "erişilebilir, güvenli, zaman ve maliyet yönünden etkin ve sürdürülebilir kentiçi ulaşım sistemlerinin oluşturulmast" (11.KP, 2019:177-180) temel amaç olarak belirlenmiştir. Kentiçi ulaşım sorunlarının aşılmasını sağlayacak politika araçları ise şunlardır (11.KP, 2019:177-180);

1. İmar ve ulaşım ana planlarının uyumunun sağlanması ve buna yönelik koordinasyon mekanizması kurulmasi.

2. Belediyelerin raylı sistem projelerinin Ulaştırma ve Altyapı Bakanlığına devredilmesi.

3. Kent içi ulaşımda toplu taşımanın özendirilmesi

4. Toplu taşıma da tek kart ödeme sisteminin uygulanması.

5. Kentiçi ulaşımda çevreci ulaşımın geliştirilmesi motorsuz ulaşım türlerinin özendirilmesi.

6. Yaya yolları ve kaldırımlar ile ilgili standartlar oluşturulması.

7. Bisiklet kullanımı ve altyapısına yönelik yasal ve finansal mekanizmalar kurulması.

8. Kent içindeki alışveriş merkezi alanlar ile tarihi ve kültürel mekanların bulunduğu yerlerin yaya bölgesi olarak düzenlenmesi

9. Ulaşım altyapısı için hazırlanan "Ulusal Strateji Belgesi ve Eylem Planı”nın uygulanması

Söz konusu politikalar çerçevesinde 2023 yılı itibariyle Bisiklet yolu uzunluğunun toplam 4.048 km'ye çıkarılması hedeflenmektedir.

Karşılaştırma ve Analiz: Onuncu planda toplu taşıma koordinasyonu, alternatif araçların özendirilmesi, raylı sistemlerin diğer ulaşım araçlarına entegrasyonu ve akıllı sistem teknolojilerinin ulaşım işletiminde kullanılmasına yönelik öngörülen politika araçları on birinci planda daha çok koordinasyon ve sonuç odaklı çözümleri içeren politika başlıkları olarak karşımıza çıkmaktadır. $\mathrm{Bu}$ çerçevede raylı sistem projelerinin özellikle finansal nedenlerle merkezi idareye devredilmesi öngörülmekte, ulaşım-imar planı koordinasyon merkezi ve ulaşım eylem planı uygulamasının uygulamaya geçirilmesi hedeflenmektedir. ${ }^{1}$ Ayrıca çevreci ulaşımın özendirilmesi yaklaşımı küresel çevre gerçekliği ve sürdürülebilir kalkınma olgusuna yönelik perspektif olarak yer almaktadır (Şekil 5).

Şekil 5. Kentiçi Ulaşım Politikalarının Karşılaştırması

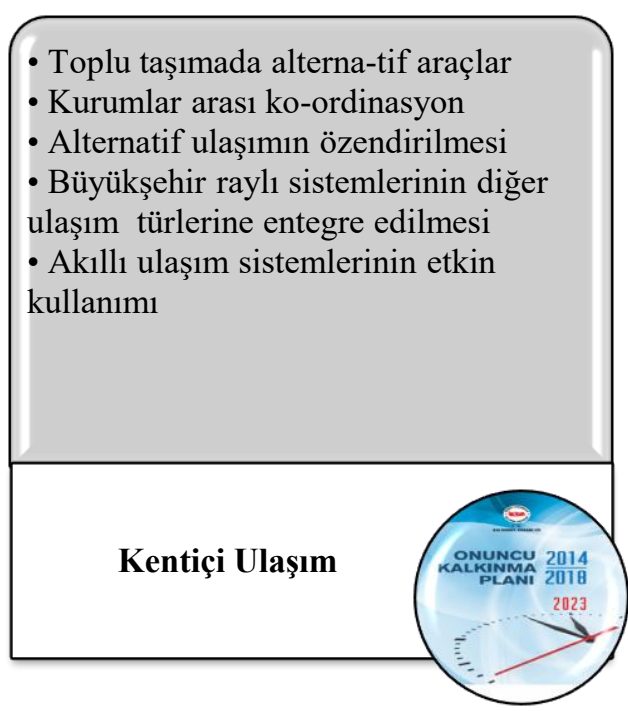

- İmar-ulaşım koordinasyon mekanizmas

- Raylı sistem projelerinin Ulaştırma ve

Altyapı Bak. devredilmesi

- Toplu taşımanın özendirilmesi

- Çevreci ulaşımın geliştirilmesi

- Yaya yolu ve kaldırım standartları

- Bisiklet altyapı mekanizmaları

- Kent merkezlerinde yaya bölgeleri

- Ulaşım Strateji Belgesi ve Eylem Planı

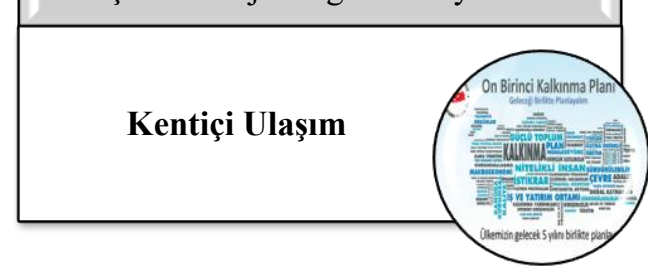

Kaynak: Yazar tarafından hazırlanmıştır.

1 UAS, Ulusal akıllı ulaşım sistemleri strateji belgesi ve eylem planı için bakınız:

http://www.ubak.gov.tr/BLSM_WIYS/SGB/tr/Pdf/20161110_090117_5643_1_88338.pdf (Erişim Tarihi: 09.09.2019). 


\subsection{Kırsal Kalkınma: Amaç ve Politikalar}

Kırsal kalkınma olgusu her iki planda özellikle büyükşehir reformu sonrasında ortaya çıkan kentsel alan yönetimi açısından ele alınmıştır.

Kırsal kalkınma (10. KP): 2012 yılında çıkarılan 6360 sayılı Kanunla, Büyükşehir sınırlarının il sınırları ile eşitlenmesi ve büyükşsehir içindeki köylerin ve belde belediyelerinin kapatılması ile oluşan alansal genişlik özellikle büyükşehir yönetimleri açısından kırsal kalkınma konusunu önemli hale getirmiştir. Kırsal kesimdeki asgari refah düzeyinin ülke ortalamasına yaklaştırılması ve kırsal ekonominin güçlendirilmesi planın temel amacı olarak öne çıkmaktadır (10. KP, 2014:134-136). Söz konusu amaca yönelik öngörülen yerel yönetim ve kent eksenli politika araçları:

1. Kırsal hizmet sunumunda yenilikçi yöntemler geliştirilmesi.

2. Köylere yönelik sosyal yardımlarda maddi durum ve yerleşim uzaklığının öncelikle dikkate alınması.

3. Kırsalın teknolojik altyapısının ve hizmet türlerinin geliştirilmesi.

4. Kırsal yatırımın geliştirilmesi.

5. Kırsal yerleşimlerde ilçe bazlı yerel kalkınma programı hazırlanması.

6. Büyükşshir ilçelerden başlayıp kırsal mahallelere hizmet sunum kapasitesinin güçlendirilmesi.

7. Kırsal alan tanımı revize edilmesi olarak belirlenmiştir.

Kırsal kalkınma (11. KP): Sürdürülebilir kırsal kalkınma anlayışıla, "kırsal işgücünün istihdam edilebilirliğinin artırllması, yaşam kalitesinin iyileştirilmesi, yoksullukla mücadele ile kirsal toplumun düzenli ve yeterli gelir imkânlarına kavuşturularak refah düzeyinin artırılması ve nüfusun kırsalda tutundurulması" (11. KP, 2019:180) planın temel amacı olarak ortaya konulmuştur. Bu noktada yerel yönetim ve kent eksenli politika araçları şunlardır (11. KP, 2019:180-183):

1. Kırsal yerleşimlerin yatırım ve hizmet ihtiyaçlarının tespiti.

2. Büyükşehirlerde mahalleye dönüşen yerleşimlerde Kırdes projesi başlatılması.

3. Köydes izleme sistemi kurulması ve Köydes projesinin devamının sağlanması. ${ }^{2}$

4. Kırsal alan imarı için tahsis edilen kaynakların etkin kullanımı ve koordinasyonu.

5. Kırsal iskan ve yaşam standartlarının yükseltilmesi için kurumsal/yerel kapasite artışı.

6. Kırsal istatistikler ve köy envanteri bilgi sistemi oluşturulması.

7. Engelli, yoksul ve yaşlı fertlere öncelik verilerek köylerde yoksullukla mücadele çalışmaları sürdürülmesi. Politika araçlarının uygulanması ile 2023 yılı itibariyle Köydes ve Kırdes kapsamında toplam $148.490 \mathrm{~km}$ köy yolu yapımının tamamlanması hedeflenmektedir.

Karşılaştırma ve Analiz: Her iki planın kırsal kalkınma ${ }^{3}$ olgusuna bakışını belirleyen temel parametre 6360 sayılı kanunla gerçekleştirilen dönüşüm olmuştur. Söz konusu dönüşüm ile büyükşsehir belediyelerinin hizmet sorumluluk alanlarının genişletilmiş olması kırsal alanları doğrudan etkilemiş ve muhatap yerel yönetim mekanizması olarak büyükşehir belediyeleri görevlendirilmiştir. $\mathrm{Bu}$ çerçevede 10 planda: kırsal hizmette yenilikçi yöntemler çerçevesinde kırsal bilişim altyapısının geliştirilmesi öngörülürken, hazırlanacak ilçe ölçekli kalkınma planları ile ilçelerin kırsal hizmet kapasitelerinin güçlendirilmesi ve kırsal yatırımın desteklenmesi hedeflenmiştir. Büyükşehir kentsel alanının değişimine bağlı olarak köy ve belde yerleşimlerinin mahalle statüsü ile büyükşehir statüsüne dahil edilmesi bu alanlara yönelik hizmet ihtiyaçlarını ve sunum biçimlerine bağlı sorun kümelerinin ortaya çıkması 11. planda büyükşehir kapsamındaki yeni adıyla kırsal mahalleleri öncelikli hale getirmiştir. Bu çerçevede Büyükşehirlerde kırdes projesi, köydes izleme sistemi, kırsal iskâna yönelik koordinasyon mekanizması ve köy envanter sistemi oluşturulması yenilikçi kurumsal modeller olarak

2 2007'de köylerin altyapısının desteklenmesi projesi (köydes) ödeneklerinin iller bazında dağılımı, kullandırılması, izlenmesi ve denetimine ilişkin esas ve usuller, İçişleri Bakanlığınca belirlenmiştir (2017/2 sayılı YPK kararı, www3.kalkinma.gov.tr > Download > Koydes_2007-2_Sayili__YPK Erişim Tarihi: 03.09 .2019 ).

3 Türkiye'de 2 tane Ulusal Kırsal Kalkınma Stratejisi hazırlanmıștır. Birincisi; 2007-2013 dönemini kapsamak üzere DPT tarafından 2006 yılında hazırlandı (https://kkp.tarim.gov.tr/Ulusal_kirsal_kalkinma_stratejisi\%20(2007-2013).pdf Erişim Tarihi: 03.09.2019). İkincisi; 2014-2020 dönemini kapsayan Ulusal Kirsal Kalkınma Stratejisi Gida Tarı ve Hayvancilı Bakanlı tar 1 tarafindan 2015'de yayınlandı (https://kkp.tarim.gov.tr/UKKS\%20(2014-2020).pdf Erişim Tarihi: 03.09.2019). 
yer almıştır ${ }^{4}$. Söz konusu politikaların kırsal yaşam standartlarının gelişimine ve kırsalda yoksullukla mücadele girişimlerinin sürmesine yönelik olduğu vurgulanmıştır (Şekil 6).

Şekil 6. Kırsal Kalkınma Politikalarının Karşılaştırması
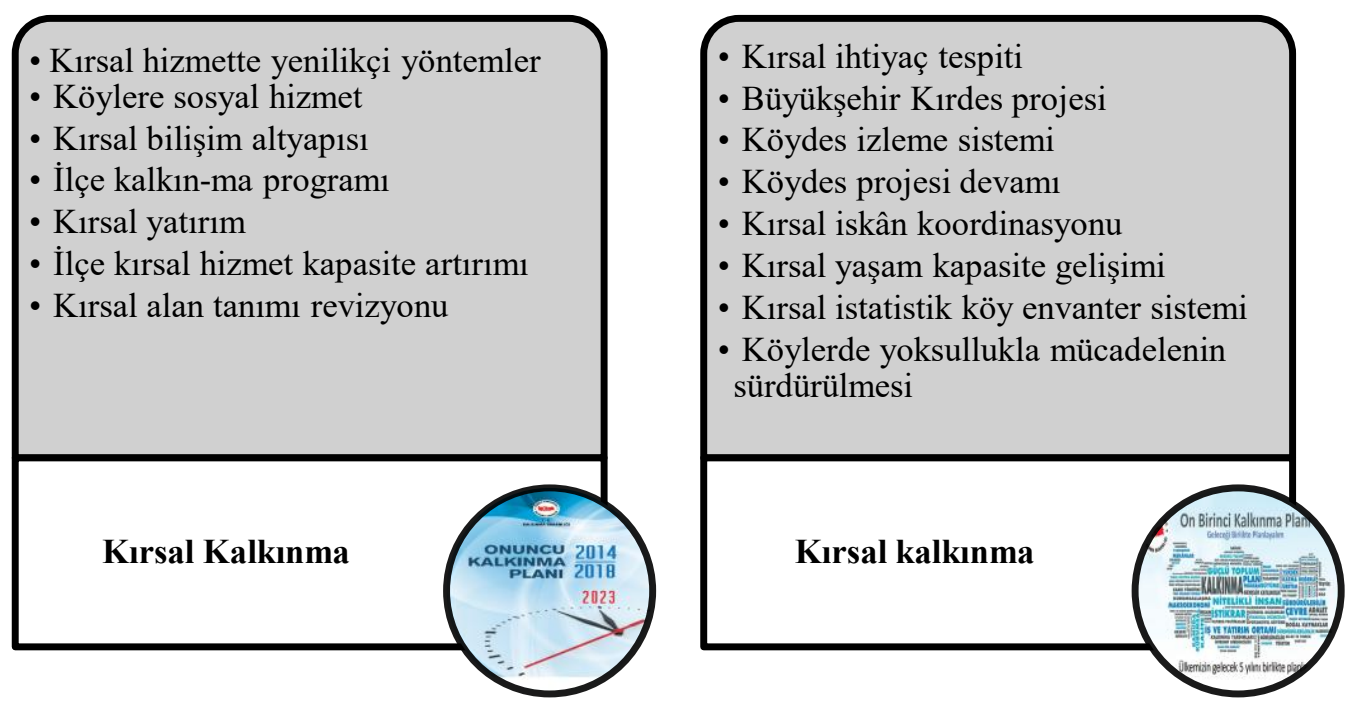

Kaynak: Yazar tarafindan hazırlanmıştır.

\section{4. Çevrenin Korunması: Amaç ve Politikalar}

Küresel çevre sorunlarının yerel odaklı çözümler çerçevesinde alınması her iki planın temel perspektifini oluşturmaktadır.

Çevrenin korunması (10. KP): Planda, sürdürülebilir kalkınma, iklim değişikliği, biyolojik çeşitliliğin korunmas1, çevre bilinci gibi küresel sorunlara yönelik politikalara yer verilmekte, uygulama ve denetim aşamalarında yerel yönetimlere yönelik rol tanımlarına rastlanmaktadır. Bu çerçevede yerel yönetim ve kent eksenli (10. KP, 2014:136-138);

1. Şehirleşme alanında çevre dostu yaklaşımlar çerçevesinde yeşil büyümenin sağlanması.

2. Çevre yönetiminde görev, yetki ve sorumluluklardaki belirsizlik ve yetersizliklerin giderilmesi.

3. Sürdürülebilir kent (ler) ilkesi çerçevesinde atık, emisyon, enerji, su, geri kazanım, gürültü vb. konularda çevre duyarlılı̆̆ınin geliştirilmesi amaç olarak belirlenmiştir.

Çevrenin korunması (11. KP): Planda çevre korumanın amacı; Çevre ve doğal kaynakların korunması, kalitesinin iyileştirilmesi, etkin, entegre ve sürdürülebilir şekilde yönetiminin sağlanması, her alanda çevre ve iklim dostu uygulamaların gerçekleştirilmesi, toplumun her kesiminin çevre bilinci ile duyarlılı̆̆ının artırılması olarak belirlenmiştir. Bu amacin realize edilmesine yönelik öngörülen yerel yönetim ve kent eksenli politika araçları şunlardır (11. KP, 2019:183-185):

1. Çevre konusunda faaliyet gösteren kuruluşların yetki ve sorumluluk alanlarının netleştirilmesi.

2. İlgili kamu kuruluşları, özel sektör, yerel yönetimler ve STK'nın işbirliğinin geliştirilmesi ile etkin çevre yönetiminin kurumsallaşması.

3. Toplumun çevre bilincinin geliştirilmesi.

4. Çevre yönetimine ilişkin kurumsal ve paydaşlara yönelik mevzuatın güncellenmesi.

4 8. KP (2001-2005) döneminde 2005 y1lında kapatılan Köy Hizmetleri Genel Müdürlüğ̈̈nün (KHGM) nin iskânla ilgili görevleri Bayındırlık ve İskân Bakanlığına, köylere ilişkin diğer görevleri ise İstanbul ve Kocaeli illerinde büyükșehir belediyelerine, diğer illerde ise il özel idarelerine devredilmiştir. Köy Hizmetleri Genel Müdürlüğ̈̈, 5286 sayılı Kanun ile kapatıldı. RG tarih: 28.1.2005 Sayı:25710. 2005 ve 2006 yıllarında köy altyapılarının iyileştirilmesi amacıyla il özel idareleri ile mahalli idare birliklerine doğrudan kaynak tahsis edilmiş ve Köylerin Altyapısını Destekleme Projesi (KÖYDES) uygulamaya konulmuştur. Ancak, kırsal yerleşim birimlerinin parçalı ve dağınık bir yapıya sahip olmaları, fiziki ve sosyal alt yapı hizmetlerinin etkin ve yaygın bir şekilde sağlanmasını sınırlandırmaktadır KHGM'nün köylere ilişkin görev ve yetkileri görev ve yetkileri 5216 sayılı Büyükşehir Kanunu ile İstanbul ve Kocaeli büyükşehir belediyelerine, diğer illerdeki köylere ilişkin hizmetler 5302 sayılı Kanun ile İl özel idarelerine devredilmiştir. 
5. Tüm coğrafi bölgelerimiz için İklim Değişikliği Eylem Planlarının hazırlanması.

6. Yerel hava kalitesi eylem planları oluşturulması.

7. Yerleşim alanlarında gürültünün yönetiminin geliştirilmesi ve stratejik gürültü haritalarının hazırlanması.

Karşılaştırma ve Analiz: Çevre koruma konusunda onuncu planda, şehirlerde yeşil büyüme ve sürdürülebilir şehirler kavramı dikkat çekmektedir. Ayrıca kurumsal açıdan çevre yönetiminde belirsizliklerin giderilmesi ve iklim değişikliği ile mücadele konusundaki sorumlulukların yerine getirilmesi, çevre duyarlılığı ve yaşam kalitesi arttırılması konuları öne çıkmaktadır. On birinci planda küresel sosyo-ekonomik rekabet ortamının sertleşmesi, teknolojik-biyolojik atık, iklim değişimi gibi küresel sorunlar ile mücadele, çevresel değerlerin korunması ve sürdürülebilir k1lınmasına ilişkin en temel araçlardan biri yerel yönetimlerin ve diğer yerel kurumsal yapıların çevre konusunda daha etkin ve belirleyici olmalarının sağlanması olarak görülmektedir. Bu çerçevede kurumsal kapasitelere yönelik olarak; kurumların görev vb. netleştirilmesi; etkin çevre yönetiminin sağlanması; çevre mevzuatının güncellenmesi; iklim değişikliği eylem planı, yerel hava kalitesi eylem planı ve stratejik gürültü haritalarının hazırlanması gibi proaktif yaklaşımlar politika başlıklarında yer almıştır. Ayrıca toplumsal çevre bilincinin geliştirilmesine yer verilmiştir (Şekil 7).

Şekil 7. Çevre Koruma Politikalarının Karşılaştırması
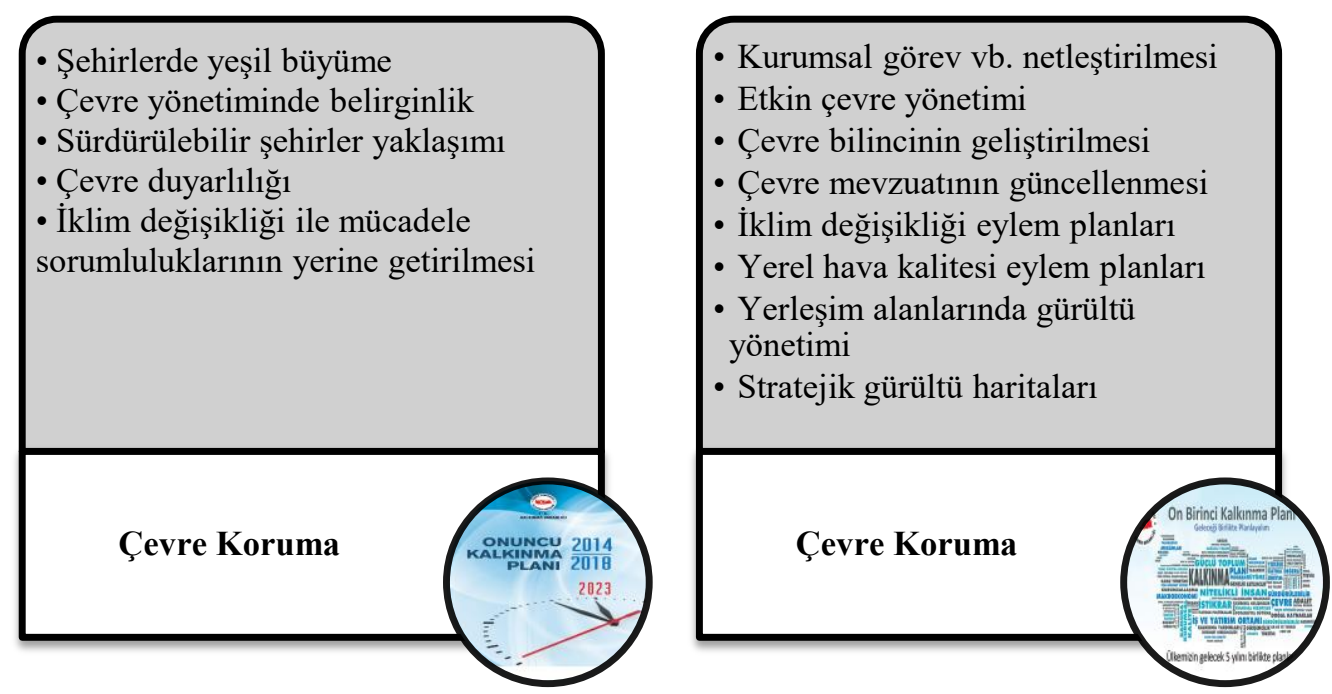

Kaynak: Yazar tarafindan hazırlanmıştır.

\subsection{Mahalli İdareler: Amaç ve Politikalar}

Onuncu planda mahalli idareler ve on birinci plan da yerel yönetimler başlıkları altında yerel kurumsal yapıya ilişkin politika ve perspektiflere yer verilmiştir.

Mahalli idareler (10. KP): Plan ile yerel yönetim ilişkisinin en net şekilde ele alındığı başlıktır ve Anayasadaki gibi Mahalli İdare kavramı kullanılmışır. Mahalli idarelerin daha etkin, hızlı ve nitelikli hizmet sunabilen, katılımcı, şeffaf, çevreye duyarlı, dezavantajlı kesimlerin ihtiyaçlarını gözeten ve mali sürdürülebilirliği sağlamış yapıya kavuşturulması; vatandaşlara sunulan hizmetlerden duyulan memnuniyeti en üst düzeye çıkarmaktemel amaçtır (10. KP, 2014:131-134). Öngörülen politikalar şunlardır:

1. Mahalli idare personelinin uzmanlaşma düzey kapasitelerinin arttırılması.

2. Büyükşehir belediyelerinde genişleyen hizmet alanları ve farklılaşan görevleriyle uyumlu düzenlemeler yapilacak.

3. Yerel ölçekli karar süreçlerine katılım araçları ve hesap verebilirlik güçlendirilecek.

4. Mahalli idarelerin yerel nitelikli gelirleri artırılacak.

5. Merkezi yönetimin yerel hizmet standartlarına ilişkin denetimlerinde etkinlik sağlanacak.

6. Köy yönetimleri idari-mali açıdan güçlendirilecek ve yerleşim sürdürülebilirliği sağlanacak. 
Yerel Yönetimler (11. KP): On birinci kalkınma planının hedef ve politikalarına ilişkin beş temel gelişme ekseninden biri olan "hukuk devleti, demokratikleşme ve iyi yönetişim" başlığında yerel yönetimler alt başlığına yer verilmiştir. Yerel yönetimlerin "etkin, hızlı ve kaliteli hizmet sunabilen; dezavantajl kesimlerin ihtiyaçlarını gözeten, katılımcı, mali sürdürülebilirliği săglamış, şeffaf ve hesap verebilir bir yapıya kavuşturularak vatandaş memnuniyetinin üst düzeye çıkarılması" (11.KP, 2019:196) temel amaç olarak belirlenmiştir. Yerel yönetimlerin kurumsal yapılarının geliştirilmesinin yanı sıra mali, teknik, personel kapasitelerinin ele alındığı, yerel demokratik işleyişe yönelik unsurlara yer verilen politika ve tedbirleri şu başlıklar altında toplamak mümkündür (11.KP, 2019:196-198):

1. Stratejik plan hazırlama zorunluluğu olan belediyelere yönelik hizmet önceliklendirme rehberi geliştirilmesi.

2. Yerel yönetim idari, mali ve teknik hizmet standartlarının belirlenmesi ve uygulamanın denetlenmesi.

3. Personelinin uzmanlaşma düzeyi ve kapasitesinin arttırılması.

4. Belediye karar alma süreçlerinde vatandaşların katılım ve denetim rolünün güçlendirilmesi.

5. Dezavantaj1ı kesimlerin yerel yönetimlerdeki katılım süreçlerinde etkinliklerinin geliştirilmesi.

6. Yerel yönetimlerin hizmet sunumlarını etkinleştirmeye yönelik yeniden yapılandırılması.

7. Yerel yönetimlerde optimum hizmet ve coğrafi alan büyüklüğü kriterlerine gore yeniden yapılanma ve mevzuat çalışması yapılması.

8. Köy yerleşim alanlarının sürdürülebilir kılıması.

9. Büyükşehirlerde tüzel kişiliği kaldırılıp mahalleye dönüşen yerlerde hizmete erişimin kolaylaştırılması.

10. Büyükşehir belediyesi ile büyükşsehir ilçe belediyelerinin çakışan yetki ve sorumlulukları etkinlik temelli olarak yeniden değerlendirilmesi.

11. Ölçeğine göre belediyelere sosyal donatı projeleri için finansman sağlanması.

12. Yerel yönetimlerin sokak hayvanlarının rehabilitasyonu projelerinin desteklenmesi.

Karşılaştırma ve Analiz: Onuncu plan mahalli idarelere yönelik kurumsal perspektifler üzerinde yoğunlaşmış görünmektedir. $\mathrm{Bu}$ çerçevede personel kapasite ve uzmanlaşmasının artırılması; yerel hizmet standartlarının uygulamasında merkezi yönetimin etkili denetimin sağlanması; köy yönetimlerinin güçlendirilmesi; mahalli idarelerin hesap verebilirliklerinin güçlendirilmesi ve kentsel taşınmazların değer artışlarının mahalli idare gelirlerine yansıtılması temel politikalar olarak öne çıkmaktadır. Tüm bu kurumsal perspektifin ana omurgasını ise Büyükşehir belediyeleriyle ilgili yeni düzenlemeler yapılacak olması şeklinde belirlenen politika başlı̆g 1 belirlemektedir. On birinci kalkınma planı dönemsel açıdan öngördüğü yerel yönetim modeline ilişkin amaç perspektifini evrensel yerel yönetim literatürüne uygun şekilde biçimlendirmiş görünmektedir. Bu çerçevede yerel yönetimlerin; yerinde ve zamanında kaliteli hizmet sunması; dezavantajlı bireyleri ve toplum kesimlerini gözetmesi; katılımcı, hesap verebilir ve mali sürdürülebilirliğe erişmiş kurumsal uygulamanın sağlanması; vatandaş memnuniyetinin arttırılması amacı belirlenmiştir. Yerel yönetimlere ilişkin söz konusu amaçların 2003 tarihli $^{5}$ kamu yönetimi temel kanun tasarısında ${ }^{6}$ ve 2004-2005 yıllarında yapılan yerel yönetim reformu kapsamında güncellenen mevzuat metinlerinde ${ }^{7}$ bulunduğunu ayrıca uygulamaya geçirilmesi öngörülen ilkesel yaklaşımların yeni kamu yönetimi anlayışının kurumsal hedefleri arasında yer aldığını söylemek gerekir (Öner, 2003:7,16,18-20;39-42;45-47;69,94,96-98). Bu noktada on birinci plan yerel yönetimler açsindan yeni bir perspektif ve vizyon koymamıştır. Önceki plan(lar)da yer alan ilkesel perspektiflerin hemen hemen tekrarlanması aynı zamanda geçmiş dönemlerde bu hedeflere ulaşıl(a)madığının itirafi olarak değerlendirilebilir. Ancak her ne kadar önceki dönemlerde de hedeflenen bu amaçlara yer verilmesi söz konusu başlıkları önemsizleştirmemekte tam tersine kavramsal çerçevenin sürdürülebilirliği ve farkındalığa yönelik ciddi bir atıf olarak görünürlüğünü arttırmaktadır (Şekil 8).

5 Kamu Yönetimi Temel Kanunu Tasarısı TBMM'de kabul edildikten sonra 5227 sayılı Kamu Yönetiminin Temel İlkeleri ve Yeniden Yapılandırılması Hakkında Kanun olarak Cumhurbaşkanlığına gönderilmiştir. C.Başkanlığınca onaylanması uygun görülmeyen kanun Cumhurbaşkanı Ahmet Necdet Sezer tarafından TBMM'ne geri gönderilmiştir (T. C. Cumhurbaşkanlığı, 2019).

6 Katılımcılık, etkinlik, şeffaflık, vatandaş odaklılık ilkeleri için Bknz., T. C. Başbakanlık, 2003:70,87,91,101,114).

7 5393-Belediye Kanunu md.9,13,14,15,76,77; 5216-Büyükşehir Kanunu md.7,10,13,15,18,24; 5302-İl Özel İdaresi Kanunu md.6,7,12,16,30,31,40,43. 
Şekil 8. Mahalli İdareler/Yerel Yönetimler Politikalarının Karşılaştırması

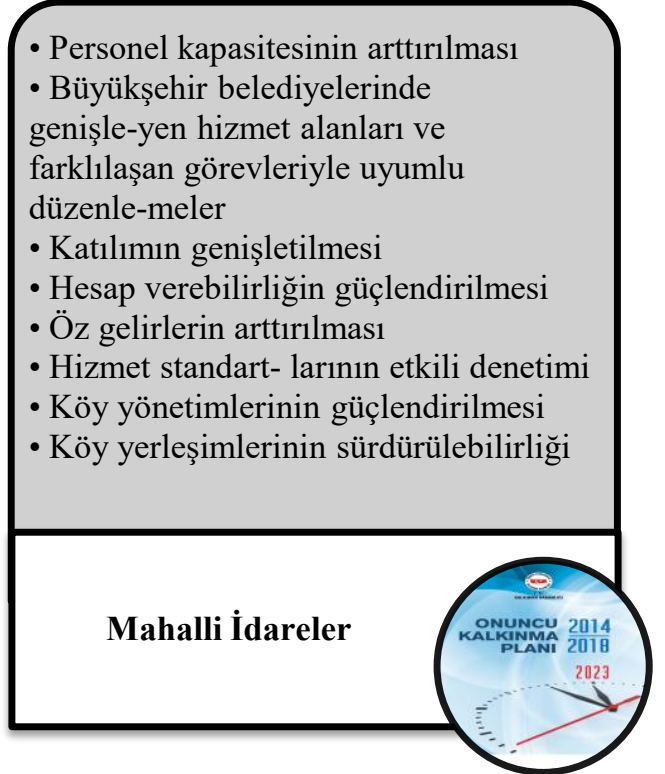

- Personel kapasitesinin arttırılması

- Büyükşehir belediyelerinde

genişle-yen hizmet alanları ve

farklılaşan görevleriyle uyumlu

düzenle-meler

- Katılımın genişletilmesi

- Hesap verebilirliğin güçlendirilmes

- Öz gelirlerin arttırılması

- Hizmet standart- larının etkili denetimi

- Köy yönetimlerinin güçlendirilmesi

- Köy yerleşimlerinin sürdürülebilirliğ

Kaynak: Yazar tarafından hazırlanmıştır.

güçlendirilmesi
- Hizmet önceliklendirme rehberi

- Hizmet standartlarına uyum denetimi

- Personel kapasitesinin arttırılması

- Vatandaş katılım-denetiminin

- Yerel yönetimlerin yeniden

yapilandirılması

- Optimum hizmet-coğrafi alan tespiti

- Köy yerleşimlerinde sürdürülebilirliğin

sağlanması

- Büyükşehirlerde mahallelerde hizmet

erişimi

- Büvüksehir beledivesi-ilce yetki vb.

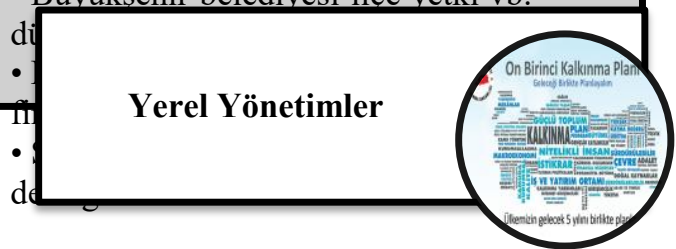

\subsection{Mekânsal Gelişme ve Planlama / Şehirleşme: Amaç ve Politikalar}

Onuncu ve on birinci planda farklı başlıklarda ele alınan konulardan biri mekânsal gelişme ve planlama ile şehirleşmedir.

Mekânsal gelişme ve planlama (10 KP): Plan kapsamında; ülkemizin coğrafi koşullarına, kent-kır ayrımına, tarihi, kültürel ve çevresel değerlerine uygun; insan ve toplum ihtiyaçlarına cevap veren, daha geniş ortak kullanım alanlarına sahip, üst standartlarda yaşanabilir mekânlara kavuşturulması temel amaç olarak belirlenmiştir (10. KP, 2014:125-127). Öngörülen politika araçlarını şu başlıklar altında toplayabiliriz:

1. Merkez-yerel ortak karar alma süreçlerini içeren mekânsal planlama.

2. Toplumun farklı kesimleri için yaşanabililik, firsat eşitliği ve hakkaniyet ilkelerini esas alan mekânsal planlama.

3. Altyapı ve ulaşım maliyetlerini azaltan şehir gelişimi.

4. Stratejik nitelikte üst ölçekli mekânsal planlama.

5. Kentsel değer artışlarından kamunun/belediyelerin yararlanması.

6. AVM'lere ilişkin ölçek ve dağılım standartları.

7. Coğrafi mekânsal bilgilerin elektronik kullanım standartları.

Şehirleşme (11. KP): Plan şehirleşme başlığı altında; "İnsan odaklı, doğal hayata ve tarihi mirasa saygılı, temel kentsel hizmetlerin adil ve erişilebilir bir şekilde sağlandığı, yaşam kalitesi yüksek ve değer üreten şehirler ve yerleşimler oluşturmak" (11.KP, 2019:172) temel amacını belirlemiştir. Öngörülen politika araçları ise şunlardır (11. KP, 2019:172-174);

1. Şehir planlanmasında, kalkınma vizyonuyla eşgüdüm içerisinde afet riski, iklim değişikliği vb. dikkate alan anlayış.

2. Şehirlerin özgün kimliğini geliştirmek üzere yerel yönetimlerin İlbank tarafından desteklenmesi.

3. Yerel yönetimlerin kırılgan kesimlere yönelik mahalle bazlı hizmetlerinin desteklenmesi.

4. Yeşil şehir vizyonu kapsamında Millet Bahçeleri. 
5. Mahalle ölçeğinden başlatılmak üzere kırsal/kent yerleşim plan süreçlerinde etkili katılım, izleme ve denetim mekanizmalar1.

6. Şehirleşmede yatay mimari.

7. Kentlilik bilincinin geliştirilmesine yönelik olarak kent bağl1lı̆g ve mahalle kültürünün geliştirilmesi.

8. Kent yerleşimlerinde "medeniyetimizi yaşatan şehir beratı" ve "özgün mahalle sertifikası" verilmesi.

9. Kentlerin yaşam kalitesini ölçme-değerlendirme araçlarının belirlenmesi.

10. Kentsel veri altyapısı oluşturulması.

11. Yerel yönetimlerin ulusal akıllı şehir stratejisi/eylem planı çerçevesinde akıllı şehir stratejileri belirlemesi.

12. Gayrimenkul değer artışlarının kentsel hizmetlere kaynak oluşturması.

Söz konusu politikalar kapsamında 2023 yılına kadar "Medeniyetimizi yaşatan şehir beratı" alan şehir sayısının 26; "Özgün mahalle sertifikası" alan yerleşme sayısının 81 olması hedeflenmektedir (11. KP, 2019:174).

Karşılaştırma ve Analiz: Onuncu planda yaşanabilir mekan perspektifi açısından prototip mekan ölçütü oluşturmak yerine; Türkiye'nin coğrafi şartları, kentsel/kırsal alan farklılıklarını dikkate alan tarihi, kültürel ve çevresel değerlere uygun, insan-toplum ihtiyaçlarına cevap verebilecek politikalar öne çıkarılmıştır. On birinci planda ise kalkınma planının yerel yönetim vizyon hedef ve politikalarını yansıması olan şehirleşme başlığı altında zaman zaman kurumsal raporlarda ve akademik metinlerde rastlanan perspektiflere yer verilmiş ve yeni önerilere getirilmiştir. Bu çerçevede; şehir planlama ve kalkınma vizyonunun eşgüdüm içinde ele alınması; Kamusal alan erişim ve güvenliğine ilişkin mahalle bazlı tedbirler geliştirilmesi; yerel yönetimlerin ihtiyaç analizi yapmaları; yeşil şehir kavramının ilk kez kullanılmış olması; Şehirlerde yatay mimarinin esas alınacak olması; kırsal ve kent planlamada paydaşların etkili katılımının sağlanması; "Medeniyetimizi yaşatan şehir berate" ve "özgün mahalle sertifikası" verilmesi; Akıllı şehir uygulamalarının teşvik edilmesi; kentsel yaşam kalitesinin ölçülmesi araçlarının geliştirilmesi konuları düzenlenmiş ve politika araçları belirlenmiştir (Şekil 9).

Şekil 9. Mekânsal Gelişme ve Planlama / Şehirleşme Politikalarının Karşılaştırması

- Yaşanabililik, firsat eşitliği ve hakkaniyeti esas alan mekânsal planlama

-Şehir ulaşım-altyapı maliyetlerinin azaltımı

-Stratejik üst ölçekli mekânsal planlama

- İmar hakkı transferinde yenilikçi araçlar

- AVM ölçek ve dağılım standartı

- Elektronik ortamda mekânsal bilgi

paylaşım standardizasyonu

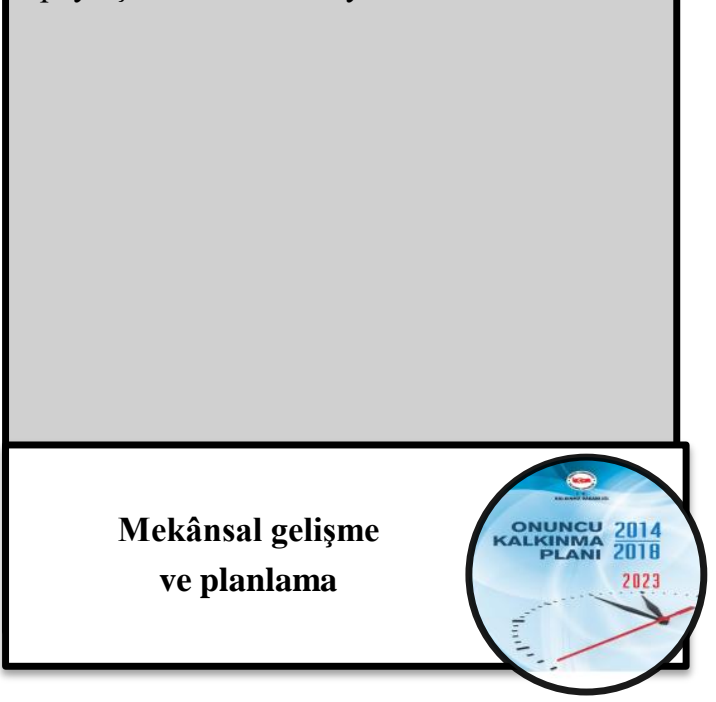

- Şehir planlanması ve kalkınma eşgüdümü -Şehir özgün kimliğini geliştirmek üzere yerel yönetimlere İlbank desteği

-Y Yönetimlerin kırılgan kesim hizmetlerinin desteklenmesi

-Millet Bahçeleri

-Yerleşim plan süreçlerinde etkili katılım ve denetim

-Şehirleşmede yatay mimari

-Ortak yaşam, aidiyet, mahalle kültürü ve kent bilinci

-Medeniyetimizi yaşatan şehir beratı

-Özgün mahalle sertifikası

-Kent yaşam kalitesi ölçme-değerlendirme araçları

-Kentsel veri altyapısı

-Y Yönetimlerde akıllı şehir stratejileri

- Gayrimenkul değer artışının kente aktarılması

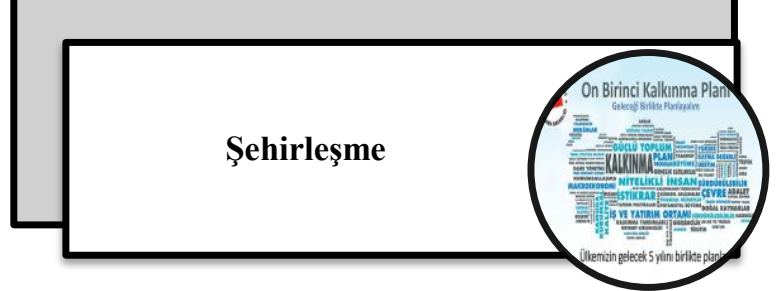

Kaynak: Yazar tarafından hazırlanmıştır. 


\subsection{Kentsel Dönüşüm ve Konut: Amaç ve Politikalar}

Ülkemizde eskimiş kentsel alanların yenilenmesi olarak açıklanan kentsel dönüşüm konut politikaları (Kedp) ile birlikte ele alınan bir süreci ifade etmektedir. İnceleme konumuz olan planlarda kentsel dönüşüm ve konut ağırlıklı noktalardan birini teşkil etmektedir.

Kentsel dönüşüm ve konut (10. KP): Şehirlerde afet riski taşıyan, altyapı darboğazı yaşayan, eski değerini ve işlevini kaybeden, mekân kalitesi düşük bölgeleri sosyal, ekonomik, çevresel ve estetik boyutlar dikkate alınarak yenilemek; kentsel refahı, yap1 ve yaşam kalitesini yükseltmek temel amaç olarak belirlenmiştir. Öngörülen politika başlıkları ise şunlardır (10. KP, 2014:127-128);

1. Afet riski taşıyan alanlar başta olmak üzere büyüme ve kalkınmaya katkı sağlayan, mekân ve yaşam kalitesini yaygın şekilde artıran Kedp'ne öncelik verilmesi. ${ }^{8}$

2. Kedp şehrin tarihi ve kültürel birikimiyle uyumlu, sosyal bütünleşmeyi destekleyen bir yaklaşımla gerçekleştirilecek.

3. Kedp'de ideal alan büyüklüğü esasları geliştirilecek.

4. Kedp finansmanında kamu harcamalarını azaltan yöntemler kullanılacak.

5. Kedp'de yenilikçi ve katma değer yaratan çevreye duyarlı üretimi destekleyen uygulamalara öncelik verilecek.

6. Dar gelirliler başta olmak üzere, halkın temel konut ihtiyacının karşılanması için önlemler alınacak.

7. Kamunun, konut piyasasındaki rolü güçlendirilecek.

8. Altyapısı hazır arsa üretimi hızlandırılacak.

Kentsel dönüşüm ve konut (11. KP): Kentsel dönüşüm açısından afet riski barındıran alanlar ile bu alanlar dışındaki riskli yapıların bulunduğu arsa ve arazilerin ilgili standartlara uygun, sağlıklı ve güvenli yaşamayı esas alacak şekilde dönüştürülmesi amaç olarak belirlenmiştir. Planda öngörülen Kedp'ne ilişkin politika araçları şunlardır (11. KP, 2019:175):

1. Kedp'de insan odakl1lı yatay mimari.

2. İl kentsel dönüşüm stratejileri.

3. Kedp'de sosyal etki analizi ve katılım.

4. Kedp önceliklendirmesinde çok ölçütlü değerlendirme modeli ve puanlama sistemi.

5. Hak sahiplerine kira vb. finansman modeli.

6. Mekânsal planlamada AFAD-Afet Riski Azaltma Sisteminin kullanılması. ${ }^{9}$

7. Afet risklerine uygun imar planlamas1.

8. Kedp'de yerli ve yenilikçi malzemelerin üretimi ve kullanımı.

2023 yılına kadar Kentsel dönüşüm strateji belgesi hazırlanan il sayısının toplam 81 olması hedeflenmektedir Konut politikaları açısından on birinci planda "dar gelirliler başta olmak üzere, herkesin yeterli, yaşanabilir, dayanıkl, güvenli, kapsayıcı, ekonomik olarak karşılanabilir, sürdürülebilir, iklim değişikliğine dirençli, temel altyapı hizmetlerine sahip konuta erişiminin sağlanması" (11. KP, 2019:175) temel amaç olarak belirlenmiştir. Bu çerçevede öngörülen politika araçları şunlardır(11. KP, 2019:175-177):

8 10. planda afet yönetimi başlığı altında afetlerin ekonomik, sosyal ve fiziki altyapı maliyetlerini yükselterek tüm sektörleri etkilemesi nedeniyle kalkınma politikalarındaki öneminin artışı vurgulanmakta önceliğin afet sonrası müdahaleye yönelik politikalar yerine afet öncesi risk azaltmaya yönelik politikalara verilmesi gereğine işaret edilmektedir (10. KP, 2014:139-140).

9 11. Planda afet yönetiminin temel amacı, afet konusunda varolan toplumsal bilincin artırılması, afetlere dayanıklı ve güvenli yerleşimlerin oluşturularak afetlerin neden olabileceği kayıpların asgari düzeye indirilmesi (11.KP, 2019:185) olarak belirlenmiştir. Bu amaca erişmek ideali çerçevesinde bölgelerin sosyo-ekonomik ve fiziksel özellikleri dikkate alınarak, farklı afet türlerine göre önceliklendirme yapılması, Türkiye afet risk azaltma planı hazırlanması, Il afet risk azaltma planları ile ülke genelinde iklim değişikliğinin etkilerine ilişkin afet ve risk haritaları hazırlanması politika araçları içinde yer almıştır (11. KP, 2019:185-188). 
1. Konut ihtiyacının arz-talep dengesi gözetilerek karşılanması.

2. Konut stoku belirlenmesi.

3. Dar gelirlilere/dezavantajlı kesime 250 bin sosyal konut üretimi.

4. Kamunun, konut piyasasında rolünün güçlendirilmesi.

5. Kamuda konut koordinasyonunun geliştirilmesi.

6. Konut standartlar geliştirilmesi.

7. Sektörde arz ve talep yönlü veri tabanı geliştirilmesi.

8. Konut talebi araştırmalarının artırılması. Söz konusu politikalar çerçevesinde plan dönemi içinde 2023 y1lına kadar toplam 270.802 konut üretimi hedeflenmektedir.

Karşılaştırma ve Analiz: Şehir merkezlerinin ve konut alanlarının değer ve işlev kaybının ortaya çıkması, bina ve yapıların eskiliğine bağlı özellikle güvenli yapı ihtiyacını ortaya çıkarırken 10. planla birlikte kentlerimizin gündemine kentsel dönüşüm projeleri (Kedp) girmiştir. Şehirlerde değerini ve işlevini kaybeden, mekân kalitesi düşük bölgeleri çevresel ve estetik boyutlar dikkate alınarak yenilemek, kentsel refahı, yapı ve yaşam kalitesini yükseltmek temel amacina yönelik perspektifler belirlenmiştir. Bu çerçevede Kedp projelerinde afet riski taşıyan alanların öncelenmesi ve sosyal bütünleşmenin desteklenmesi beklentileri ön plan çıkarılmıştır. Plan 1930/1580 sayılı kanunda belediyelere ve 1980'lerden tibarende TOKI'ye ait bir görev olarak tanımlanan konut ihtiyacının karşılanmasına yönelik olarak dar gelirliler başta olmak üzere halkın temel konut ihtiyacının karşılanması için önlemler alınmasını ve kamunun, konut piyasasındaki rolü güçlendirilmesini öngörmüştür. (10. KP, 2014:127-128). Sonuçları ve yaşanan süreçler açısından kent tarihimiz en önemli başlıklarından olan kentsel dönüşüm konusu on birinci planda da yer almaktadır. Planda "yatay mimari" esası ile yaşam kalitesini yükseltme ve kentlilik bilincini geliştirme amacını hedefleyen Kedp öngörülmüştür. İl bazında kentsel dönüşüm stratejileri izlenmesi sürecinde sosyal etki analizlerinin yapılması, katılımın esas alınması, dönüşüm alanlarındaki vatandaşlara kira yardımı vb. finansal destekler sağlanması öngörülmüsstür. On birinci planda konut politikaları açısından dar gelirlilerin öncelenmesi kaydıyla herkesin yaşanabilir, güvenli temel altyapı hizmetlerine sahip konut erişiminin sağlanması amacına yönelik olarak konut stoku, piyasanın düzenlenmesi, konut standardizasyonunun geliştirilmesi ve izlenmesi, arz-talep perspektifli konut veri tabanı oluşturulması başlıklarında politika ve tedbirler geliştirilmiştir (Şekil 10).

Şekil 10. Kentsel Dönüşüm ve Konut: Politika ve Tedbirler (11. KP)
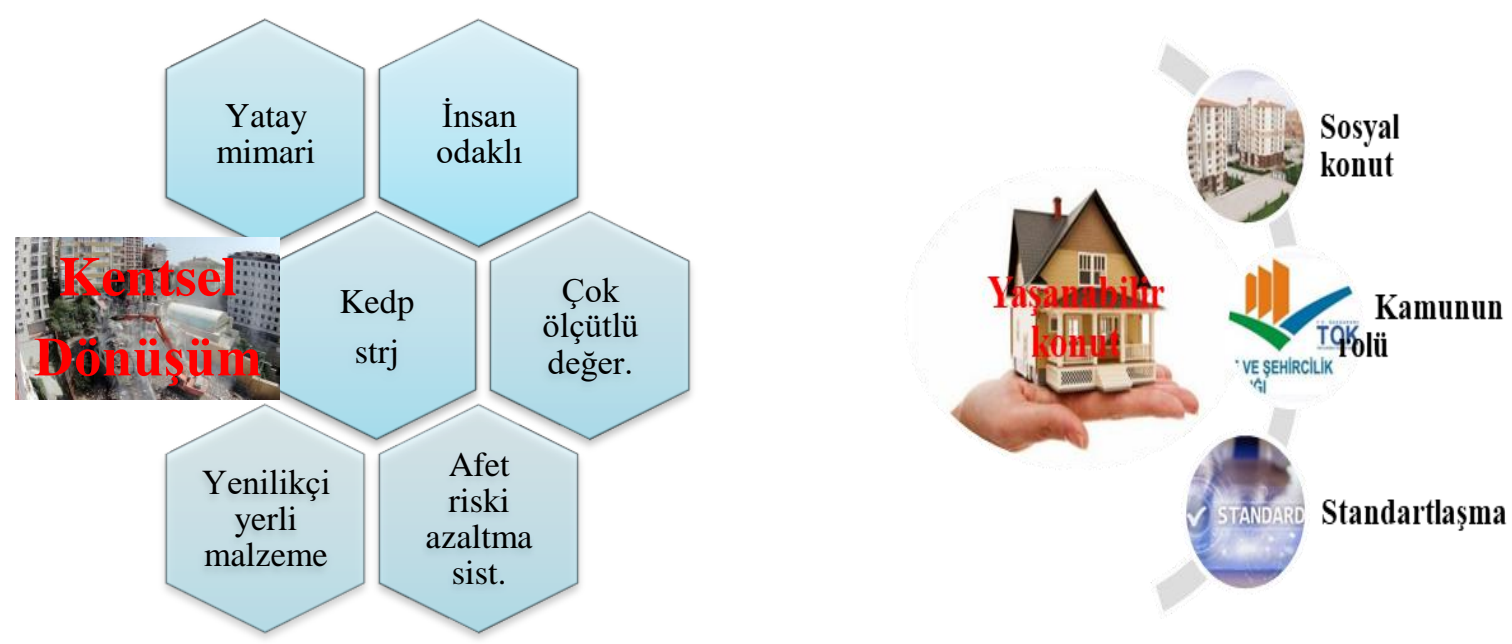

Kaynak: Yazar tarafından hazırlanmıştır. 


\section{SONUÇ VE DEĞERLENDİRME}

Çalışma konumuzun sınırlarını belirlediğimiz onuncu ve on birinci Kalkınma Planları kurumsal sorumluluk açısından temel bir farklılık göstermektedir; Onuncu Kalkınma Planı Başbakanlık ve Kalkınma Bakanlığının kurumsal sorumluluğu altında tamamlanan bir süreci yansıtırken, On Birinci Plan CHS'nin yönetsel açıdan sağladığı değişimin bir göstergesi olarak Cumhurbaşkanlığı Strateji ve Bütçe Başkanlığı ile Hazine ve Maliye Bakanlığının müşterek sorumluluğunda işletilen süreç ile tamamlanmıştır. Her iki plan kentsel yaşam alanlarına hemen hemen aynı temel başlık altında yer vermiştir: Yaşanabilir Şehirler (Mekanlar) Sürdürülebilir Çevre. Temel yaklaşım benzerliği içeriğe de yansıtılmış görünmektedir; Kentsel Altyapı, Kırsal Kalkınma, Çevrenin Korunması her iki planda aynı kavramsal başlıklar ile yer almıştır. Yerel yönetimler (mahalli idareler), Şehirleşme (mekânsal gelişme ve planlama) başlıkları benzer sorun alanlarına yönelmekle birlikte farklı başliklar altında ele alınmıştır.

Kentsel altyapı politika ve amaçları açısından onuncu plan içme suyu ve kanalizasyon altyapısının tamamlanması ve bu konuda mali sürdürülebilirliğe atıf yaparken on birinci plan bu konuda su bilgi sistemi, sukap ve kurumsal yapılanma gibi kurumsal, stratejik ve eylem planı ağırlıklı politika perspektifi öngörmektedir. Onuncu plan atık yönetimini etkin kılmayı, on birinci plan ise kentsel altyapı açısından stratejik bakış ve eylem odaklı politikalara yer vermektedir. Onuncu planda toplu taşıma araçlarına yönelik koordinasyon ve entegrasyon olarak belirlenen politika araçları on birinci planda sonuç odaklı çözümleri içeren politika başlıkları olarak karşımıza çıkarken ayrıca küresel çevre gerçekliği ve sürdürülebilir kalkınma olgusuna yönelik perspektiflere atıf sayılacak şekilde "çevreci ulaşım yaklaşımı" öngörülmektedir. Her iki planın ele alma gerekçelerinin temel belirleyicisi 2012 y1lında yürürlüğe konulan 6360 sayılı yasal düzenleme olmakla birlikte kırsal kalkınmanın önemine açık bir güçlü vurgu yapılmaktadır. Büyükşehir reformu sonrasında hazırlanmış olmasının izlerini yansıtan biçimde yenilikçi yöntemler içermesini öngörülen ilçe ölçekli kalkınma planları ile ilçelerin kırsal hizmet kapasitelerinin güçlendirilmesi ve kırsal yatırımın desteklenmesi onuncu planın hedefi olarak belirlenmiştir. Büyükşehir kentsel alanında yaşanan değişimine bağlı olarak hizmet ihtiyacı sorun kümelerinin ortaya çıkması on birinci planda büyükşehir kapsamındaki yeni adıyla kırsal mahalleleri öncelikli hale getirmiştir. Bu çerçevede büyükşehirlerde kırdes projesi, köydes izleme sistemi, kırsal iskâna yönelik koordinasyon mekanizması ve köy envanter sistemi oluşturulması yenilikçi kurumsal modeller olarak yer almıştır. Çevre koruma ve kentsel alan konusunda onuncu planda, şehirlerde yeşil büyüme ve sürdürülebilir şehirler kavramı dikkat çekmekte iklim değişikliği ile mücadele konusundaki sorumlulukların yerine getirilmesi öne çıkmaktadır. On birinci planda küresel sosyo-ekonomik rekabet ortamının sertleşmesi, teknolojik-biyolojik atık, iklim değişimi gibi küresel sorunlar ile mücadele konularında yerel yönetimlerin daha etkin ve belirleyici olmaları öngörülmekte bu çerçevede iklim değişikliği eylem planı, yerel hava kalitesi eylem planı ve stratejik gürültü haritalarının hazırlanması gibi proaktif yaklaşımlara politika başlıklarında yer verilmiştir.

Mahalli idareler ve Yerel Yönetimler başlıkları altında her iki planda temel sorun alanlarına yer verilmektedir. Onuncu plan mahalli idarelere yönelik kurumsal perspektifler üzerinde yoğunlaşırken; personel kapasitesinin artırılması; yerel hizmet standartlarının uygulamasında merkezi yönetimin etkili denetimin sağlanması; köy yönetimlerinin güçlendirilmesi; mahalli idarelerin hesap verebilirliklerinin güçlendirilmesine temel politikalar olarak yer verilmektedir. On birinci kalkınma planında temel ulusal metinlerde yer alan evrensel yönetsel karşı1lığ bulunan temel perspektiflere yer vermektedir. Bu çerçevede yerel yönetimlerin; etkin, hızlı ve kaliteli hizmet sunması; katılımcı, şeffaf ve hesap verebilir kurumsal yapı vatandaş memnuniyeti vb. amaç olarak belirlenmiştir. Mekansal gelişme ve Şehirleşme başlıkları altında planların yaklaşımları temel perspektifler açısından önemli farklar içermektedir. Onuncu planda yaşanabilir mekan hedefine yönelik olarak coğrafi koşullar, kent-kır ayrımı tarihi/kültürel/çevresel değerleri önceleyen insan ve toplum ihtiyaçlarına cevap veren politika araçlarına yer verilmiştir. Şehirleşme başlı̆̆ında on birinci plan geçmiş dönem kurumsal/akademik rapor ve metinlerdeki önerilere yer vermiştir. Bu çerçevede; kentsel planlama ve kalkınma eşgüdümü; yerel yönetimlerin ihtiyaç analizleri; yeşil şehir; yatay mimari; kırsal ve kentsel planlama süreçlerine paydaşların etkili katılımı; medeniyetimizi yaşatan şehir beratı; özgün mahalle sertifikası ve akıllı şehir uygulamaları temel politika ve tedbirler olarak belirlenmiştir. Her iki planın önemli akslarından birini kentsel dönüşüm oluşturmaktadır. Özellikle kent merkezli bina ve yapıların eskiliğine bağlı güvenlik ihtiyacını ortaya çıarması ile onuncu plan gündemine kentsel dönüşüm projelerini getirmiş ve afet riski taşıyan alanların öncelenmesi ve sosyal bütünleşmenin desteklenmesi beklentilerini öne çıkarmıştır. Plan halkın temel konut ihtiyacının karşılanması için önlemler alınmasını ve kamunun, konut piyasasındaki rolü güçlendirilmesini öngörmüştür. On birinci planda yatay mimari anlayışıyla, yaşam kalitesini yükseltme ve kentlilik bilincini geliştirme amacına yönelik kentsel dönüşüm projeleri öngörülmüştür. Bu çerçevede dar gelirliler öncelenerek herkesin yaşanabilir, 
güvenli temel altyapı hizmetlerine sahip konut erişiminin sağlanması amacına yönelik olarak konut stoku, piyasanın düzenlenmesi, konut standardizasyonunun geliștirilmesi ve izlenmesi, arz-talep perspektifli konut veri tabanı oluşturulması başlıklarında politika ve tedbirler geliştirilmiştir.

Cumhurbaşkanlığı Hükümet Sisteminin ilk planı olması dolayısıyla önem taşıdığından söz ettiğimiz on birinci kalkınma planında yerel yönetimlere ilişkin yaklaşımlar açısından dört ana perspektif dikkati çekmektedir. Birincisi: Planda geçmiş dönem planlarında yer alan kavramsal unsurların tekrar ediliyor görünmesi. İkincisi: Küresel açıdan sosyo-ekonomik, siyasal, kültürel, teknolojik ve uluslararası toplumun gündeminde olan gelişmelerin toplumun beklentilerine cevap verecek şekilde yönetsel, kurumsal vb. değişimlerle eklemlemeye yönelik vizyon ve politika tedbirlerinin belirlenmiş olması. Üçüncüsü: Küresel rekabet şartlarına uyum, yerel kalkınma ve rekabet şartlarına hazırlık noktasında kent ve kırsal kalkınma bir arada ele alınmış ve üstelik kentbölge olgusu yeni bir yaklaşım olarak belirlenmiştir. Dördüncüsü: Yerel ölçekte toplumsal beklentilerin karşılanmasına yönelik Büyükşehir modeli merkezli yine ve yeniden yerel yönetim reformunun güçlü şekilde vurgulanmış olması. On birinci planın yerel yönetimler açısından gündem belirleyecek perspektifi ise Büyükşehir modeli eksenli "yine ve yeniden" yerel yönetim reformunun güçlü şekilde vurgulanmış olmasıdır. Planda açıkça ortaya konulan büyükşehir temelli reform beklentisinin kalkınma planına yansımasını ve büyükşehir modeli başta olmak üzere yerel yönetimlerde yeniden yapılanma ihtiyacına yönelik vurguları şu başl1klar altında toplayabiliriz:

1. Yerel yönetimlerin optimum hizmet ve coğrafi alan büyüklüğüne göre çoklu ölçüt tasnif sistemine gore yeniden yapılandırılmas1

2. Büyükşehir ve ilçe belediyelerinin yetki ve sorumluluklarının yeniden değerlendirilmesi

3. Büyükşehirlerde köy/belde iken mahalleye dönüşen yerleşim alanlarına yönelik Kırdes projesi uygulanmas1

4. Büyükşehir dışındaki il ve ilçelerdeki kırsal ve belde yerleşimleri için Köydes projesinin devam ettirilmesi

5. Büyükşehirlerde köyden mahalleye dönüşen yerlerde hizmete erişimin kolaylaştırılması

6. Kent esenliği ve güvenliğinin güçlendirilmesi

Büyükşehir modelinde en son 6360 sayılı kanunla yapılan değişiklik sonrasında büyükşehir işleyişi, belde ve köylerin kapatılıp mahalle statüsüne dönüştürülmesi, büyükşsehir ve ilçe belediyeleri arasında yetki ve sorumluluk çakışmaları vb. sorunların aşılmasına yönelik mevzuat ve kurumsal güncellemeye gidilmesi önerisi getirildiği görülmektedir (Şekil 11).

Şekil 11. On Birinci Plan Beklenti Analizi

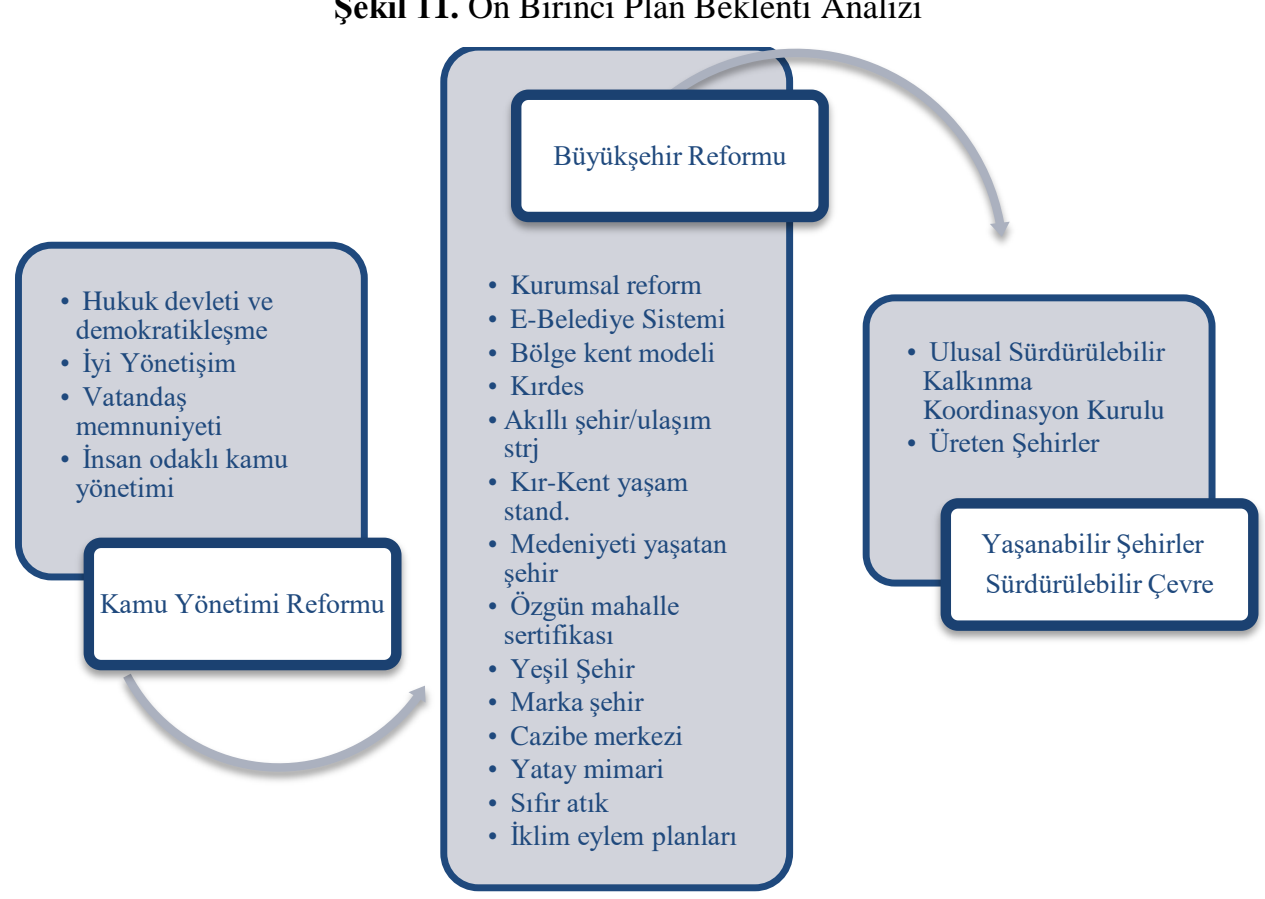

Kaynak: Yazar tarafından hazırlanmıştır. 
Öte yandan on birinci kalkınma planın çeşitli başlıklarında da yerel yönetimler ve kentsel alan sorunlarına ilişkin perspektiflere ilişkin politika başlıklarına yer verilmektedir.

1. İstikrarlı ve güçlü ekonomi; Yerel yönetimlerin öz gelirleri artırılacak; Belediye Gelirleri Kanunu yeniden düzenlenecek.

2. İş ve yatırım ortamı; Yerel yönetimlerin yatırım izinlerine ilişkin uygulamaları basitleştirilecek; Ebelediye uygulaması yaygınlaştırılacak; Üreten Şehirler Programı geliştirilecek.

3. Sektörel politikalar; Yerel yönetimlerde yatırım projelerine ilişkin standardizasyon sağlanacak; Cumhurbaşkanlığında mahalli idare yatırım projelerinin ve harcamalarının izlendiği yapı kurulacak.

4. Lojistik ve ulaştırma; Akıllı kentiçi ulaşım sistemleri yerel yönetimleri kapsayacak şekilde tamamlanacak.

5. Ailenin güçlendirilmesi; Aile bireylerinin birlikte zaman geçirebilecekleri aile dostu çevre ve mekânların yaygınlaşması için yerel yönetimler desteklenecek. Sosyal hizmetler, sosyal yardımlar ve yoksullukla mücadele; kamu kurumlarının yerel yönetimlerle karşılıklı veri paylaşımı sağlanacak. Kırsalda sosyal yardımlara erişim açısından yerel yönetimlerin rolü artırılacak.

6. Kültür ve sanat; Kültür yapıları ulaşılabilir, yaygın ve cazip yapılar şeklinde tasarlanacak; yerel yönetimlerin markalaştırma uygulamaları teşvik edilecek.

7. Nüfus ve yaşlanma; Evde bakım hizmetlerinde yerel yönetimlerin rolü genişletilecek.

8. Hukuk devleti ve demokratikleşme; Yerel yönetimler saydam ve hesap verebilir yapıya kavuşturulacak

9. İyi yönetişim; Kent konseylerinin daha aktif hale getirilmesine yönelik düzenleme yapılacak

10.Kamu hizmetlerinde e-Devlet uygulamalar1; e-Belediye bilgi sistemi projesinin tamamlanmas1.

11.Sürdürülebilir kalkınma amaçları (SKA); Cumhurbaşkanlığı Strateji ve Bütçe Başkanlığı Ulusal Sürdürülebilir Kalkınma Koordinasyon Kurulunda yerel yönetimlerin katılımının sağlanması.

\section{KAYNAKÇA}

DPT - T. C. BAŞBAKANLIK DEVLET PLANLAMA TEŞKİLATI (2007), 1. Ulusal Kırsal Kalkınma Stratejisi (2007-2013), DPT Yayını, Ankara,

https://kkp.tarim.gov.tr/Ulusal_kirsal_kalkinma_stratejisi\%20(2007-2013).pdf (Erişim Tarihi: 03.09.2019).

ÖNER, Şerif (2003), Türkiye'de Belediye Yönetimi, Nobel Yayınları, Ankara.

T. C. BAŞBAKANLIK KANUNLAR VE KARARLAR GENEL MÜDÜRLÜĞÜ (2003), Kamu Yönetimi Temel Kanunu Tasarısı, https://www.tbmm.gov.tr/sirasayi/donem22/yil01/ss349m.htm (Erişim Tarihi: 09.09.2019).

T. C. CUMHURBAŞKANLIĞI (2004), "5227 sayılı 'Kamu Yönetiminin Temel İlkeleri ve Yeniden Yapılandırılması Hakkında Kanun"', Kurumsal Basın Açıklaması, https://www.tccb.gov.tr/basin-aciklamalari-ahmetnecdet-sezer/1720/6352/5227-sayili-kamu-yonetiminin-temel-ilkeleri-ve-yeniden-yapilandirilmasihakkinda-kanun.html (Erişim Tarihi: 09.09.2019).

T. C. CUMHURBAŞKANLIĞI STRATEJİ VE BÜTÇE BAŞKANLIĞI (2019), Onbirinci Kalkınma Planı: 2019-2023, T. C. Cumhurbaşkanlığı Strateji ve Bütçe Başkanlığı Yayını, Ankara, http://www.sbb.gov.tr/wp-content/uploads/2019/07/On-Birinci-Kalkinma-Plani.pdf (Erişim Tarihi: 03.09.2019).

T. C. GIDA TARIM VE HAYVANCILIK BAKANLIĞI (2015), 2. Ulusal Kırsal Kalkınma Stratejisi (20142020), Gıda Tarım ve Hayvancılık Bakanlığı Yayını, Ankara, https://kkp.tarim.gov.tr/UKKS\%20(20142020).pdf (Erişim Tarihi: 03.09.2019).

T. C. KALKINMA BAKANLIĞI (2019), On Birinci Kalkınma Planı (2019 - 2023), Özel İhtisas Komisyonları ve Çalışma Grupları Eı Kitabı, Kalkınma Bakanlığı Yayını, Ankara. 
T. C. ULAŞTIRMA DENIZCILİK VE HABERLEŞME BAKANLIĞI (2016), Ulusal AUS Strateji Belgesi Eki Eylem Planı (2014/2016) Gelişme Raporu, UDH Bakanlığı Strateji Geliştirme Başkanlığı Yayını, Ankara, http://www.ubak.gov.tr/BLSM_WIYS/SGB/tr/Pdf/20161110_090117_5643_1_88338.pdf (Erişim Tarihi: 09.09.2019).

TBMM (2013), Onuncu Kalkınma Planı: 2014-2018, (06.07.2013 tarih ve 28699/mükerrer sayılı Resmi Gazete).

5216 sayılı Büyükşehir Kanunu (23.07.2004 tarih ve 25531 say1lı Resmi Gazete).

5286 sayılı Köy Hizmetleri Genel Müdürlüğünün Kaldırılması ve Bazı Kanunlarda Değişiklik Yapılması Hakkında Kanun (28.01.2005 tarih ve 25710 say1lı Resmi Gazete).

5302 sayılı İl Özel İdaresi Kanunu (04.03.2005 tarih ve 25745 say11 Resmi Gazete).

5393 sayılı Belediye Kanunu (13.07.2005 tarih ve 25874 sayılı Resmi Gazete).

1 nolu Cumhurbaşkanlığı Teşkilatı Hakkında Cumhurbaşkanlığı Kararnamesi (10.07.2018 tarih ve 30474 say1l1 Resmi Gazete).

13 nolu Strateji ve Bütçe Başkanlığı Teşkilatı Hakkında Cumhurbaşkanlığı Kararnamesi (24.07.2018 tarih ve 30488 say1l Resmi Gazete).

Kırsal Kalkınma Programı İzleme Komitesinin Teşekkülü ve Çalışma Esasları Hakkında Yönetmelikte Değişiklik Yapılmasına Dair Yönetmelik (23.07.2019 tarih ve 30840/mükerrer sayılı Resmi Gazete).

On Birinci Kalkınma Planı Hazırlıkları İle İlgili 2017/16 sayılı Başbakanık Genelgesi (29.07.2017 tarih ve 30138 say1lı Resmi Gazete).

2017/2 sayılı 2007 Yılı Köylerin Altyapısının Desteklenmesi Projesi (Köydes) Ödeneklerinin İller Bazında Dağılımı, Kullandırılması, İzlenmesi ve Denetimine İlişsin Esas Ve Usuller Hakkında YPK Kararı, www3.kalkinma.gov.tr > Download > Koydes_2007-2_Sayili_YPK (Erişim Tarihi: 03.09.2019). 